\title{
A Review on the Sorghum for biofuel and microRNAs
}

\author{
Syeda Hafsa Ali ${ }^{1}$, Muhammad Younas khan Barozai ${ }^{1 *}$, Muhammad Din ${ }^{1}$ \\ and Ahmad Naseer Aziz ${ }^{2}$ \\ 1. Department of Botany, University of Balochistan, Quetta-Pakistan \\ 2. Department of Agriculture and Environmental Sciences, Tennessee State University, 3500 John A. Merritt \\ Boulevard Nashville, TN, United States of America \\ *Corresponding author's email: barozaikhan@gmail.com \\ Citation \\ Syeda Hafsa Ali, Muhammad Younas khan Barozai, Muhammad Din and Ahmad Naseer Aziz. A Review on the \\ Sorghum for biofuel and microRNAs. Pure and Applied Biology. Vol. 5, Issue 4, pp1064-1100. \\ http://dx.doi.org/10.19045/bspab.2016.50131
}

\begin{tabular}{llll}
\hline \hline Received: 04/07/2016 & Revised: 04/08/2016 & Accepted: 08/08/2016 & Online First: 20/08/2016 \\
\hline
\end{tabular}

\section{Abstract}

Energy is lifeline in development and progress of a country, with pivotal use in industrial and agricultural sectors. While fossil fuels are primary source of energy, its rapid depletion is major concerns of the world today. Developed countries are finding alternates to strengthen its economic backbone by resolving limited supply of energy issues and meeting their enormous demands. Plants can offer better alternative as biofuels to address the energy crisis and meet projected energy demand. Recently, sorghum based research remained center of attention due to its exceptional properties to grow under dry, and hot environmental conditions with limited water requirement. All parts of sorghum have economic values with usage in syrup, sugar, fuel, alcohol, bedding and paper production. Whereas, Sorghum stalks are enriched source of carbohydrates with 16-18\% of fermentable sugar that makes it potential candidate for bioethanol production. Bioethanol is considered environmental friendly as it reduces greenhouse gases and replaces MTBE (Methyl tert-butyl ether) pollutants in air. Yet, the benefits of sorghum as biofuels comes with a challenge of rapid degradation of sugar, therefore immediate harvest after maturity can ensure high sugar content. This review covers scope and recent research on sorghum in Pakistan and indicates its usage as an ideal feedstock to meet present energy crisis. Currently, developed countries are exploiting sorghum in bioethanol production due to its high tolerance to drought and salt, and improved sugar content in lieu of using sugarcane and maize. Moreover, studies involving high-tech research and role of microRNA in high yield and improved sugar content in biofuel production of sorghum are also addressed in this review.

Keywords: Sorghum; Biofuels; miRNA; Bioethanol; Economic and environmental concerns

\section{Introduction}

\section{Sorghum based research in Pakistan}

Pakistan is an agriculture based country with variety of important cereal crops, including sorghum. Sorghum ranks fifth among important cereal crops of the world, and is top summer grass of Pakistan and commonly called as 'Jawar.' It is widely used as staple food for humans besides its usage as fodder for animals. Sorghum is warm-weather crop and adapted to wide range of soil and climate conditions [1]. Its grain comprises of $70 \%$ carbohydrates, $10-12 \%$ protein and $3 \%$ fats, while fodder is highly enriched with 
prussic acid and oxalic acid, therefore grains can be introduced in feeding programs for poultry and cattle [2]. Around 2.35 million hectares of land, contributing in $12 \%$ of the cultivated land is cropped area for fodder production in Pakistan (Agricultural Statistics of Pakistan, 2005). Though production of good quality forage requires well organized livestock industry, food crop land cannot be compensated for the fodder cultivation. Therefore, legumes are intercultured with cereal and forage crops to increase fodder supply. Although cereal crops give high yield, their protein content is lower than legumes [3]. Yield of sorghum is higher even from small farm area as compared to other plants however, the forecasted values of sorghum production revealed decrease in cultivation trend in near future. This decrease in cultivation trend is due to improper use of sorghum for industrial purpose and use of low yielding varieties [4]. Nevertheless, the research on sorghum has been increased in recent years while advancing from physio-morphological characteristics. Previously, germplasm characterization was performed using physiological, morphological or isozyme markers. Recently, DNA finger printing has removed the barriers in germplasm characterization by providing enough genetic information that was unavailable at phenotypic level. Tabbasum and her coworkers [5] distinguished two sorghum hybrids while identifying $78.98 \%$ genetic resemblance among them using random amplified polymorphic DNA (RAPD) [5].

Advancement in molecular techniques has helped identifying genetic diversity among crops and thus use of agronomic, physiological and morphological traits have been improvised to the level of biochemical and molecular markers. A study conducted by Mehmood et al. [6] approached phylogenetic relationship and genetic diversity of 10 sorghum varieties through
RAPD analysis, and found $78.94 \%$ polymorphism. Through their work sorghum varieties, YSS-9 and 84G01 showed distant relationship, while RARI-S3 and RARI-S-4 were found to be closely related [6]. Sorghum has diverse genome, therefore, genetic fingerprinting provides an efficient marker system. In 2010, another genetic diversity study on 29 sorghum varieties was conducted among exotic, and approved local lines using RAPD, revealing 95\% polymorphism among the varieties. They found that the genotypes of exotic lines KA-113 and Indian III exhibited maximum similarity, whereas F-606 and F-601 showed distinctive features [7].

Till date genotypes of many crops are evaluated using physiological markers, as recent study [8] evaluated drought tolerance in sorghum (80 accession) using physiological parameters revealing significant differences in all accessions under stress. Osmotic pressure was considered potential trait for drought tolerance, while five accessions (80265, 80114, SS-95-4, SS-97-7 and 80377) were found widely tolerant to water stress [8]. Furthermore, a study conducted on role of exogenous salicylic acid in salinity tolerance on post germination seedlings (PARI-S-4 and YSS-9) revealed that low level of salicylic acid reverse the impact of salinity in seedlings but at high salt concentration (50 mg L-1): beyond threshold causing high level of $\mathrm{Na}+/ \mathrm{K}+$ ratio, salicylic acid was found ineffective in reducing salinity [9]. Another study on determining effect of exogenous proline in reducing impact of salinity in sorghum cultivars revealed that low concentration $(50 \mathrm{mM})$ of proline boost physiological characteristics of sorghum, whereas as high concentration $(100 \mathrm{mM})$ together with high salt concentration alleviated the adverse effect caused by salt stress [10]. Akram et al. [11] determined genetic variability for drought tolerance in 
20 genotypes of sorghum cultivars using 10 RAPD primers. Maximum similarity of 95.5\% was noted between YSS-17 and PARC-SS-1 genotypes, while minimum similarity of $51.5 \%$ was observed for DS97-1 genotype. Furthermore, maximum similarity was observed between YSS-10 (C) and YSS-18, YSS-98 and SV-10, CSV15 and Rasili, VI-1 and RS-29 [11]. In another study, 17 of sorghum landraces were evaluated for grain yield and drought tolerance using physio-morphological markers at seedling and post flowering stages, revealing high genetic difference in water stress tolerance for higher grain yield [12]. Hussain et al. [13] evaluated eight genotypes of sorghum of Potohar region for various grain and associated traits, showing significant difference in grain yield, plant height, stalk yield, days to $50 \%$ flowering and maturity. Among tested varieties of sorghum, SPV-462 was stalk producing variety with higher grain yield, whereas Johar and CSP-15 SPV were high grain producing varieties, while SPV and YSS were high stalk producing varieties. Among the sorghum varieties tested, PARC-SS-2 took minimum days to $50 \%$ flowering, whereas, CSV-15 and YSS-9 took longest time to $50 \%$ flowering [13]. Sher et al. [14] investigated the effect of harvest time associated with $\mathrm{P}$ and $\mathrm{S}$ fertilization on yield and quality of forage sorghum (Sorghum bicolor (L.) Moench). They concluded that harvesting at maturity stage along with $\mathrm{P}$ and $\mathrm{S}$ fertilization increases forage yield and other quality related traits as: $30 \%$ decrease in leaf hydrocyanic acid content, and 50\% increase in stalk soluble-solid content widely used as an indicator of forage juiciness and palatability [14]. Furthermore, a study [15] on effect of potash fertilizer dose on sorghum hybrid (Pioneer MRBuster) and maize hybrid (Pioneer 3062) showed high grain yield with increase in potash level and number of split applications. Potash fertilizer caused significant differences in all parameters except for plant height, thus, highest grain yield was recorded in maize (8014 kgha-1) with three-split dose of 120 kgha-1, as compared to control with minimum grain yield. Therefore, recommended application of $120 \mathrm{kgha}-1$ of potash fertilizer with 3 splits can help improve grain yield for both crops [15].

In Pakistan, salinity is among major challenges that adversely affect the yield and growth of crops to various extents. Therefore, cultivation of salinity tolerant lines can bring solution to obtain economical yield. Kausar et al. [16] screened physiological parameters of sorghum lines to identify salinity tolerance. Among all sorghum lines, Sandalbar and JS-2002 were considered tolerant, while JS-263 and Hegari had medium tolerance. Sorghum line Noor was conceived as medium sensitive, whereas, PSV-4 and FJ-115 were found sensitive to salinity [16]. Another study for effects of heavy metal $(\mathrm{NiCl})$ on morphological characteristics of sorghum demonstrated that increasing concentration up to $90 \mathrm{ppm}$ (of $\mathrm{NiCl}$ ) can adversely reduce dry weight of sorghum while 30ppm was considered minimum threshold level [17]. Seed priming technique widely used to stimulate the seed emergence and seedling growth has been studied by Shehzad et al. [18] to evaluate effect of these different techniques such as: un-soaked seed (control), Halopriming with KNO3 and $\mathrm{CaCl} 2$ (1\% solution), Hydro-priming (soaked with distill water) etc. On germination and seedling growth of three sorghum varieties (JS-2002, Hegari, and JS263). All priming techniques accelerated germination rate by $50 \%$, while Halopriming with $\mathrm{KNO} 3$ and $\mathrm{CaCl} 2$ helped improving seedling growth and sorghum emergence [18]. Genetic potential of 20 sorghum genotypes was evaluated for drought 
tolerant traits (heritable and measurable) after artificially creating water stress via PEG treatment and five (80353, 80365, 80199, 80204 and 80319) were found superior to be used in drought tolerant breeding programs. Therefore, crops at early growth stages can be screened using different heritable morphological parameters for drought stress [19]. Seven advanced lines of sorghum, i.e., Noor, Hegari, F9917, F-207, F-214, JS-2002 and PC-1 were evaluated for nutritive profile as well as dry matter and forage material, and Hegari genotype was found superior in terms of forage material as well as nutritive dry matter due to high leaf area [20]. F-9917 and F-214 displayed poor performance in terms of ash content, crude protein and fiber needed to be served for forage purpose. These finding on new genotypes revaled that genetic variation among sorghum genotypes can contribute in potential traits for forage purpose and therefore, can be exploited [20]. Although hydrogen cyanide $(\mathrm{HCN})$ is associated with it, sorghum is considered main forage crop for livestock. Zahid et al. [21] determined the effects of $\mathrm{HCN}$ content at different growth stages (of plant, i.e., 3rd leaf (GS1), pre-booting (GS2) and 50\% heading stage (GS3) and post cutting) for local sorghum cultivars: including JS-2002, and Chakwal sorghum. Sorghum JS-2002 was considered safe for forage purpose due to high crude protein percentage, lowest $\mathrm{HCN}$ content and, higher crude fiber at prebooting stage. Moreover, though the content of $\mathrm{HCN}$ was found high in young and early growth stages, yet it decreased and crude fiber increased in mature and advanced growth stages. Furthermore JS-2002 cultivar, at GS2 stage, presented lowest content of HCN after $18 \mathrm{hrs}$ of post cutting [21]. Individual and combined allelopathic effects of root/shoot powder and water extract of sunflower and sorghum applied on soil were evaluated for seed emergence and growth of rice and weeds: (Dactyloctenium aegyptium, Trianthema portulacastrum and Eleusine indica.Sorghum) and it was found that sunflower water extract caused high inhibitory effects by reducing $50 \%$ time required for seed emergence compared to the powder treatments [22].

During 2011, a new sorghum hybrid variety was introduced for general cultivation in Pakistan. This dual purpose sorghum hybrid Sorghum 2011 was developed by crossing Australian No.7 (exotic) with Sugrorib (local) through pedigree breeding method in year 1998-99. During 2002-03 to 2009-10 homozygous progenies no. F6-6019 were bulked to evaluate various traits for high yield and uniform fodder, and Sorghum2011 hybrid showed exceptional performance compared to Hegari, JS-263 and JS-2002 existing cultivars, in terms of high nutritional value, low fertilizer requirement, improved water efficiency, high grain yield, robust growth, wide adaptability and green fodder with minimum HCN content [23]. Akhtar et al. [24] demonstrated impact on quality of forage sorghum when these were sown individually or together with forage legumes. Quality and quantity of forage sorghum intercropped with forage legumes, was significantly higher as there was better mixed green forage yield obtained when forage sorghum was grown in $30 \mathrm{~cm}$ apart rows and cluster bean was in between the rows [24].

Another study was done on response of sorghum varieties JS-263 (old cultivar), JS2002 and Chakwal Sorghum (recent cultivars) on different levels of soil moisture using physiological and morphological traits. At high soil moisture JS-2002 showed higher potential than Chakwal Sorghum while JS-263 - old genotype showed insufficiency to face drought. Therefore, JS2002 and Chakwal Sorghum holds promising future in areas subjected to dry spells [25]. Hayyat et al. [26] demonstrated 
the effects of viable textile effluent concentrations, on physiology of Sorghum vulgare Pers CV-5000. They concluded, that the plant growth was adversely affected by maximum concentration of textile effluents which was found injurious in comparison to control [26]. Six sorghum parent varieties (V-1, SV-6, CVS-13, SPV462, RARI-S-10, TSS-9) and nine crosses were evaluated for fodder yield by heterosis and combining ability, revealing significant difference for all the traits under assessment. This study [27] indicated that a significant improvement in fodder yield of crosses is possible due to better and robust performance of these genotypes than parent heterosis along with good general combiner parents (V1, CVS-13). One of such sorghum line TSS-9 was selected for number of tillers per plant, while V-1 presented highest GCA for plant height, and CVS-13 was noted for stem thickness, fresh weight per plant, and dry weight per plant [27]. In a study eight sorghum varieties (JS-2002, JS-263, MRSorghum-2011, Hegari, Pak-China-1, Sandal Bar, F-7017 and F-114) compared for yield and other quality related attributes, showed significant difference in dry matter yield, morphological traits, forage yield, and quality parameters (Table 1). Pak-China 1 had difference in maximum number of traits, while F-114 differed in minimum traits. F7017 and Sandal bar showed maximum crude protein and crude fiber compared to other varieties [28]. Raza and Naheed [29] determined correlation of high yield and its related biometric characteristics among sorghum hybrids improving yield. Thier results concluded that biometric characteristics: such as yield and plant population; number of green leaves and plant population; plant height and yield were positively correlated [29].

In another study sorghum accessions (10) were evaluated for drought tolerance and showed great variability for water stress tolerance at seedling stage. Among all traits studied in the young seedlings; shoot related traits were found highly sensitive to water stress. Thus accession No.1749 was considered drought tolerant, while F-2007 and F-2008 were found drought susceptible [30]. Kausar et al. [31] explored variation in physiological parameters due to salinity stress related to nitrogen metabolism of sorghum (Table 1). The sorghum genotypes having efficient $\mathrm{N}$-metabolism were considered tolerant due to high biomass production under saline stress. Salinity influence was less in sorghum lines JS- 2002 and Sandalbar and thus were categorized as tolerant, while Noor was found to be medium sensitive and FJ-115 was labeled as sensitive one [31].

Recently, a new pathogen Curvularia lunata (Wakk.) was identified from the leaves of sorghum in Punjab Province, Pakistan. Early symptom indictae small reddish brown lesion that further increases in size and merges to form oblong lesion with chlorotic centers and affects the entire field. This pathogenic strain showed $99 \%$ of 584-bp sequence resembles with $C$. lunata strain pingxiang a causative agent of leaf spots of lotus particularly in China. Curvularia species are known for causing leaf spot disease in various grass species, yet identification $C$. lunata on $S$. bicolor in Pakistan is among primitive reports [32]. Kandhro et al. [33] demonstrated economical, effective and eco-friendly weed management strategy by intercropping sorghum dwarf variety MR-Buster, sunflower hybrid Hysun-39 and cotton seeds variety Sindh-1. Their results showed that intercropping of these three seeds, i.e cotton, sorghum and sunflower can significantly enhance yield and reduce $59.6 \%$ of weeds. Moreover, twice inter-culturing can decrease $67.5 \%$ of weeds whereas application of Dual Gold 960 EC controlled $53.4 \%$ of weed, while significant strengthening the 
cottonseed yield. The analysis of variance showed that intercropping of sorghum or sunflower with cotton suppressed weeds significantly by $59.6 \%$, respectively and significantly enhance growth, while interculturing twice reduced further weeds and gave significantly higher cottonseed yield. Among all the strategies, total crop productivity was highest through intercropping of sunflower and sorghum with cotton as compared to Dual Gold 960 usage in term of cottonseed yield [33].

A study conducted by Mehmood et al. [34] evaluated impact of mulching (no mulch application, poultry manure mulch, and wheat straw mulch) and tillage application (zero tillage, reduced tillage and conventional tillage) on soil fertility and sorghum grain productivity. Poultry mulching enhanced soil fertility and sorghum grain yield significantly higher than other mulching practices, while tillage affected all soil properties except organic matter, and soil $\mathrm{pH}$, whereas conventional tillage was found superior for grain yield. Their study concluded that limited poultry manure mulching and tillage can improve soil properties and sorghum grain yield [34]. A field experiment [35] determined growth and efficient uptake of nitrogen (N), potassium $(\mathrm{K})$ and phosphorus $(\mathrm{P})$ in sorghum from different organic components [Humic acid (HA), Farmyard manure (FYM), and Press mud (PM) and its compost from rock phosphate] in sorghum. The grain and dry mass yield, as well as plant height and uptake of nutrients significantly increased due to organic composts in saline effected soil. Therefore, different types of organic compounds have potential to improve growth by increasing nutrient uptake in saline effected soils [35]. Crop breeding is an excellent strategy to increase plant yield and producing stress resistant varieties. Ten sorghum genotypes were tested through physio-morphological traits for their resistance toward drought stress, together with impact of drought on fodder yield and quality. Three different levels of water stresses $(100 \%, 75 \%$, and $50 \%$ ) provided to sorghum genotypes revealed variable results. Sorghum-11 and NARC-11 were reported to be drought tolerant, while F-114 was found drought sensitive [36]. Sorghum genotypes differed from each other on the basis of morphological traits, through a study conducted by Ghani et al. [37] that evaluated grain and other quality associated traits in sorghum. Their study reported following: YSS-17, YSS-10 (Cream), and YSS-9 were high grain producing, while YSS-10 (Cream) and YSS-9 also showed high fodder yield. YSS-98 (control) was reported for $50 \%$ flowering in minimum 79 days, whereas, YSS-10 (Cream) took maximum 86 days to $50 \%$ flowering. Among the tested genotypes, the study showed YSS-9 as dualpurpose variety with grain having no tannin contents and high grain and fodder yields [37]. Twenty four genotypes of sorghum including SS 97-2 (S1), PARC-SS-1, No. 1500, No. 1692, T-3-DADU, 1572-T, S-986, SS-95-4, No. 1761, No. 1542, No. 1620 , No. 1728, SP-1832, SS-97-10, SS 98-3, No.1828 (2001), F-9806, R-19, No. 1623, BR-123，PARC-SV-2，SS-95-RG，SS-95$\mathrm{RG}$ and BMR-RED UNI) were tested for morphological traits and yield to determine heritability, genetic variability, and genetic advance. The results revealed high variability for all the studied characteristics, whereas phenotypic co-efficient of variation was slightly higher than genotypic coefficient of variation. This study indicated that expression of physiological and morphological traits were highly heritable in sorghum population and can be exploited to improve crop productivity in breeding program [38]. Another study on fodder yield potential of nine sorghum varieties through evaluating morphological characteristics 
showed, significant differences in fodder yield, number of leaves and leaf area, yet plant height was found insignificant trait. Number of leaves was highly variable among all varieties, yet variety-Local Tandojam gave highest yield, whereas variety Giza-3 had the lowest yield [39].

A study was conducted on phyto-extraction of heavy metals: like lead, chromium, and cadmium (along with EDTA as chelating agent) having different concentrations at various physiological levels in sorghum. The study revealed that the heavy metal accumulation of cadmium, chromium, lead, and EDTA adversely affected shoot length, fresh weight and dry weight of $\mathrm{S}$. bicolor. The metal uptake and accumulation also increased by increasing metal concentration, whereas $5 \mathrm{mM}$ EDTA enhanced metal uptake [40]. Sorghum and sunflower contains several allelochemicals inhibitory metabolites now used as natural and cost effective tool for weed suppression. A study tested impact of inter-culturing:, Dual Gold 960, sorghum and sunflower water extracts different concentrations and intervals, as well as sorghum and sunflower water extracts in combination with Dual Gold 960, for controlling weeds (Table 1). The results suggested that application of sorghum water extract in combination with Dual Gold reduced $66.6 \%$ weeds with improved yield of cottonseed allowing maximum income benefits, followed by sunflower combined with Dual Gold that lowered $65.5 \%$ weeds, while lastly sole application of Dual Gold reduced weeds by $55.9 \%$ with low yield of cottonseed. Nevertheless, inter-culturing twice exponentially suppressed $67.7 \%$ of weeds, yet had low income benefits as compared to sorghum and sunflower water extracts in combination with Dual Gold. Therefore, sorghum water extract with Dual Gold showed maximum benefits in terms of net income, yield and low weed [41]. Another study conducted on allelopathic effect of sunflower and sorghum powder via soil incorporation and water extracts, showed substantial reduction of germination and morphological traits of cotton seedlings. Allelopathic effects of sorghum powder on growth and morphological traits of cotton seedlings were found superior compared to water extracts. Therefore, utilizing the allelopathic potential of sorghum and sunflower can be effective strategy for weed management [42].

Table 1. Sorghum based research in Pakistan

\begin{tabular}{|c|c|c|c|c|}
\hline S. No. & Sorghum variety & Purpose & Result & Refs. \\
\hline 1. & Two hybrids of Sorghum & $\begin{array}{l}\text { RAPD analysis to } \\
\text { find DNA } \\
\text { polymorphisms }\end{array}$ & $\begin{array}{l}8(40 \%) \text { primers detected } \\
\text { polymorphism between the } \\
\text { hybrids, } 33 \% \text { were } \\
\text { polymorphic }\end{array}$ & [5] \\
\hline 2. & $\begin{array}{l}10 \text { Sorghum varieties: DS-97-1, 84- } \\
\text { Y-00, RARI-S-3, RARI-S-4, Mr. } \\
\text { Buster, 86-G-87, 84-Y-01, 85-G-83, } \\
\text { PARC-SS-1, YSS-9 }\end{array}$ & $\begin{array}{l}\text { Molecular } \\
\text { characterization }\end{array}$ & $\begin{array}{l}\text { (RARI-S3 and RARI-S-4 are } \\
\text { closest; YSS-9 and } 84 \mathrm{G} 01 \\
\text { show distant relationship) }\end{array}$ & [6] \\
\hline 3. & $\begin{array}{l}\text { 29 Sorghum: Hegari Noor, JS-2002 } \\
\text { F-507 F-603 F-505 F-215 FJ-9601 F- } \\
9809 \text { F-502 F-9917 F-2012 F-9606 } \\
\text { F-2022 F-214 F-2020 F-2018 F-9706 } \\
\text { F-9603 F-604 F-601 F-508 F-606 } \\
\text { Indian III, Australian-7 K-A-113 } \\
\text { Australian-6 China small A82L-36 }\end{array}$ & $\begin{array}{l}\text { Genetic divergence } \\
\text { among genotypes, } \\
\text { using RAPD } \\
\text { markers }\end{array}$ & $\begin{array}{l}\text { Highest similarity between } \\
\text { Indian III and K-A-113 (both } \\
\text { exotic lines), while the F-601 } \\
\text { and F-606 were most diverse } \\
\text { genotypes }\end{array}$ & [7] \\
\hline
\end{tabular}


Hafsa Ali et al.

\begin{tabular}{|c|c|c|c|c|}
\hline 4. & $\begin{array}{l}\text { Sorghum Seed of } 80 \text { Sorghum } \\
\text { accessions }\end{array}$ & $\begin{array}{l}\text { Drought tolerance } \\
\text { through } \\
\text { physiological } \\
\text { markers }\end{array}$ & $\begin{array}{l}\text { Five accessions }(80265, \\
\text { 80114, SS-95-4, SS-97-7 \& } \\
\text { 80377) were tolerant }\end{array}$ & [8] \\
\hline 5. & $\begin{array}{l}\text { Two Sorghum lines, viz., PARI-S-4 } \\
\text { and YSS-9 }\end{array}$ & $\begin{array}{l}\text { Role of exogenous } \\
\text { salicylic acid in } \\
\text { salinity tolerance }\end{array}$ & $\begin{array}{l}\text { Application of } 25 \text { ppm SA was } \\
\text { effective in salt tolerance }\end{array}$ & [9] \\
\hline 6. & Two cultivars of Sorghum & $\begin{array}{l}\text { Salt tolerance by } \\
\text { exogenous } \\
\text { application of } \\
\text { proline }\end{array}$ & $\begin{array}{l}\text { Proline alleviated the adverse } \\
\text { effects of salt stress }\end{array}$ & [10] \\
\hline 7. & $\begin{array}{l}\text { Rari-S-4, SPV-462, } \\
\text { CSV-15, RS-29, PARC-SV-10, YSS- } \\
\text { 9, PARC-SS-2, Johar }\end{array}$ & $\begin{array}{l}\text { Evaluation of } \\
\text { physiological } \\
\text { parameters }\end{array}$ & $\begin{array}{l}\text { SPV-462, CSP-15 and Johar } \\
\text { produced higher grain yield, } \\
\text { YSS-9 and SPV-462 produced } \\
\text { higher stalk yield, } \\
\text { YSS-9 and CSV-15 took } \\
\text { maximum days to 50\% } \\
\text { flowering while variety } \\
\text { PARC-SS-2 took minimum } \\
\text { days to 50\% flowering. } \\
\text { PARC-SS-2 and Johar showed } \\
\text { earliness to mature, while } \\
\text { YSS-9 matured late }\end{array}$ & [13] \\
\hline 8. & $\begin{array}{l}\text { Seeds of } 20 \text { Sorghum (RASILI, VI-1, } \\
\text { SPV-462, CSV-13, DS-97-1, PARC- } \\
\text { SS-1, RARI-S-3, RARI-S-4, YSS-9, } \\
\text { RS-29, PARC-SS-2, YSS-98, YSS- } \\
10 \text { (Red), YSS-10 (Cream), YSS-17, } \\
\text { YSS-18, YSS-19, SV-10, JV-2002, } \\
\text { CSV-15) }\end{array}$ & $\begin{array}{l}\text { Drought tolerance } \\
\text { (using 10 RAPD } \\
\text { primers }\end{array}$ & $\begin{array}{l}\text { DS-97-1, SPV- 462, YSS- } \\
\text { 10(R), YSS-19, JV-2002, } \\
\text { PARC-SS-2 and CSV-13 were } \\
\text { found genetically diverse } \\
\text { (genotypes are an important } \\
\text { source for drought tolerance) }\end{array}$ & [11] \\
\hline 9. & Chakwal Sorghum (var Moench) & $\begin{array}{l}\text { effect of harvest } \\
\text { time associated } \\
\text { with } P \text { and } S \\
\text { fertilization on } \\
\text { yield and quality } \\
\text { of forage }\end{array}$ & $\begin{array}{l}\text { Quality traits are improved } \\
\text { when plants were harvested at } \\
\text { a more advanced maturity }\end{array}$ & [14] \\
\hline 10. & Seventeen Sorghum landraces & $\begin{array}{l}\text { Exploited to } \\
\text { establish morpho- } \\
\text { physiological } \\
\text { criteria for drought } \\
\text { tolerance and } \\
\text { higher } \\
\text { grain yield in } \\
\text { sorghum at } \\
\text { seedling and post } \\
\text { flowering stages }\end{array}$ & $\begin{array}{l}\text { Morpho-physiological markers } \\
\text { can be exploited for drought } \\
\text { tolerance in breeding } \\
\text { programme }\end{array}$ & [12] \\
\hline 11. & $\begin{array}{l}\text { Maize hybrid (Pioneer 3062) and } \\
\text { Sorghum hybrid (Pioneer MR- } \\
\text { Buster) }\end{array}$ & $\begin{array}{l}\text { Effect of split } \\
\text { doses of potash } \\
\text { fertilizer on maize } \\
\text { and Sorghum }\end{array}$ & $\begin{array}{l}\text { In sorghum and maize } \\
\text { maximum grain yield was } \\
\text { recorded with the application } \\
\text { of } 120 \text { kgha- } 1 \text { of Potash with } \\
\text { three splits. }\end{array}$ & [15] \\
\hline 12 . & $\begin{array}{l}\text { JS-2002, JS-263, Hegari-Sorghum, } \\
\text { PSV- 4, Sandalbar, Noor, FJ-115 }\end{array}$ & Salinity tolerance & $\begin{array}{l}\text { JS-2002 and Sandalbar } \\
\text { (tolerant), Hegari- sorghum }\end{array}$ & [16] \\
\hline
\end{tabular}




\begin{tabular}{|c|c|c|c|c|}
\hline & & & $\begin{array}{l}\text { and JS-263 (medium tolerant), } \\
\text { Noor (medium sensitive), FJ- } \\
115 \text { and PSV-4 (sensitive) }\end{array}$ & \\
\hline 13 & $\begin{array}{l}\text { Twenty accessions of Sorghum ( var } \\
\text { Moench) 80353, 80365, 80199, } \\
\text { 80204, 80319, SS-97-7, 80174, SS- } \\
\text { 95-4, 80077, 80265, 80369, 80374, } \\
\text { 80381, 80236, 80203, 80376, 80158, } \\
\text { 80364, 80114, 80214 }\end{array}$ & Drought tolerance & $\begin{array}{l}\text { promising drought tolerant } \\
\text { accessions }(80353,80365, \\
80199,80204 \text { and } 80319)\end{array}$ & [19] \\
\hline 14 & $\begin{array}{l}\text { Three Sorghum genotypes: Hegari, } \\
\text { JS-263 and JS-2002 }\end{array}$ & $\begin{array}{l}\text { Effect of Seed } \\
\text { priming techniques } \\
\text { on seed emergence } \\
\text { and seedling } \\
\text { growth }\end{array}$ & $\begin{array}{l}\text { seed priming accelerates } \\
\text { emergence of sorghum }\end{array}$ & [18] \\
\hline 15 & $\begin{array}{l}\text { Seven lines of Sorghum: Hegari, } \\
\text { Noor, F-214, JS-2002, F-207, PC-1 } \\
\text { and F- } 9917\end{array}$ & $\begin{array}{l}\text { Performance of } \\
\text { forage material } \\
\text { and nutritional } \\
\text { profile of dry } \\
\text { matter }\end{array}$ & $\begin{array}{l}\text { Hegari was preferred for } \\
\text { forage purpose }\end{array}$ & {$[20]$} \\
\hline 16 & \begin{tabular}{|l|} 
JS-2002, Chakwal \\
Sorghum and local cultivar
\end{tabular} & $\begin{array}{l}\text { Identify the } \\
\text { suitable cultivars } \\
\text { having low HCN } \\
\text { content Stress } \\
\text { disrupts normal } \\
\text { growth and } \\
\text { contribute toward } \\
\text { increased HCN } \\
\text { toxicity. } \\
\text { Common cause of } \\
\text { HCN in sorghums } \\
\text { is drought }\end{array}$ & $\begin{array}{l}\text { JS- } 2002 \text { has the lowest HCN } \\
\text { content }\end{array}$ & {$[21]$} \\
\hline 17 & Sorghum (Sorghum bicolor L.) & $\begin{array}{l}\text { Effect of } \mathrm{NiCl} \\
\text { (salt) }\end{array}$ & $\begin{array}{l}\text { Morphological parameters } \\
\text { effected at high concentration }\end{array}$ & [17] \\
\hline 18 & Sorghum and Sunflower & $\begin{array}{l}\text { Allelopathic } \\
\text { effects of water } \\
\text { extracts of } \\
\text { sorghum and } \\
\text { sunflower alone } \\
\text { and in combination } \\
\text { on the germination } \\
\text { and seedling } \\
\text { growth of rice and } \\
\text { weeds }\end{array}$ & $\begin{array}{l}\text { sorghum with sunflower water } \\
\text { extracts showed more } \\
\text { inhibitory effects on } \\
\text { germination }\end{array}$ & {$[22]$} \\
\hline 19 & $\begin{array}{l}\text { Sorghum-2011: a cross Sugrorib } \\
\text { (local) } \times \text { Australian No.7 (exotic), } \\
\text { Sorghum-2011, JS-2002, JS-263, } \\
\text { Hegari }\end{array}$ & $\begin{array}{l}\text { Develop dual } \\
\text { purpose sorghum } \\
\text { cultivar }\end{array}$ & $\begin{array}{l}\text { Sorghum-2011 superior than } \\
\text { other cultivars }\end{array}$ & {$[23]$} \\
\hline 20 & Sorghum bicolor L. & $\begin{array}{l}\text { Agro-qualitative } \\
\text { response of forage } \\
\text { sorghum (Sorghum } \\
\text { bicolor L.) sown } \\
\text { alone and in } \\
\text { mixture with }\end{array}$ & $\begin{array}{l}\text { Sorghum intercropped with } \\
\text { cluster bean produced } \\
\text { significantly higher mixed } \\
\text { green forage yield }\end{array}$ & [24] \\
\hline
\end{tabular}


Hafsa Ali et al.

\begin{tabular}{|c|c|c|c|c|}
\hline & & forage legumes & & \\
\hline 21. & $\begin{array}{l}\text { JS-2002, Chakwal Sorghum and JS- } \\
263\end{array}$ & $\begin{array}{l}\text { Growth response } \\
\text { in drought }\end{array}$ & $\begin{array}{l}\text { (JS-2002 and Chakwal } \\
\text { Sorghum) }\end{array}$ & [25] \\
\hline 22. & Sorghum vulgare Pers CV-5000 & $\begin{array}{l}\text { Effects of textile } \\
\text { effluent }\end{array}$ & $\begin{array}{l}\text { Textile effluents are injurious } \\
\text { at high concentrations. }\end{array}$ & {$[26]$} \\
\hline 23. & $\begin{array}{l}\text { Nine Sorghum crosses and their six } \\
\text { parents (V-1, SV-6, CVS-13, } \\
\text { SPV-462, RARI-S-10, TSS-9) }\end{array}$ & $\begin{array}{l}\text { Estimation of } \\
\text { heterosis for } \\
\text { fodder yield }\end{array}$ & $\begin{array}{l}\text { Heterosis in fodder yield is } \\
\text { feasible } \\
\text { Better combiner parents (V1, } \\
\text { CVS-13) }\end{array}$ & {$[27]$} \\
\hline 24. & $\begin{array}{l}\text { Ten different accessions of Sorghum: } \\
\text { F.C-26-I, NO.1749, F.S.9902, F- } \\
\text { 2007, AK-113, NOOR, F-2-2007, F- } \\
\text { 2008, M.R-SORG- 2011, F-114. }\end{array}$ & $\begin{array}{l}\text { Drought tolerance } \\
\text { at seedling stage }\end{array}$ & $\begin{array}{l}\text { Promising drought tolerant } \\
\text { accession (NO.1749) and } \\
\text { drought susceptible (F-2007 } \\
\text { and F-2008) }\end{array}$ & {$[30]$} \\
\hline 25. & $\begin{array}{l}\text { Eight forage Sorghum cultivars: JS- } \\
\text { 2002, JS-263, MR- Sorghum-2011, } \\
\text { Hegari, Pak-China-1, Sandal Bar, F- } \\
7017 \text { and F-114 }\end{array}$ & $\begin{array}{l}\text { Comparative } \\
\text { performance of } \\
\text { different sorghum } \\
\text { forage cultivars } \\
\text { regarding yield } \\
\text { and quality } \\
\text { attributes }\end{array}$ & $\begin{array}{l}\text { Maximum physiological value } \\
\text { recorded in Pak-China-1 } \\
\text { followed by F-114, and } \\
\text { minimum in Sandal-Bar } \\
\text { Crude protein and crude fiber } \\
\text { were more in Sandal bar and } \\
\text { F-7017 }\end{array}$ & {$[28]$} \\
\hline 26. & $\begin{array}{l}\text { Two tolerant (JS-2002 and } \\
\text { Sandalbar) and two sensitive (Noor } \\
\text { and FJ- 115) Sorghum genotypes }\end{array}$ & $\begin{array}{l}\text { Salinity induced } \\
\text { changes in } \\
\text { nitrogen } \\
\text { metabolism of } \\
\text { sorghum }\end{array}$ & $\begin{array}{l}\text { Salinity influenced Noor as } \\
\text { medium sensitive and FJ-115 } \\
\text { sensitive. Sorghum lines JS- } \\
2002 \text { and Sandalbar were } \\
\text { tolerant, Noor medium } \\
\text { sensitive and FJ-115 as } \\
\text { sensitive }\end{array}$ & {$[31]$} \\
\hline 27. & $\begin{array}{l}\text { Seeds of cotton: variety Sindh-1, } \\
\text { Sorghum dwarf variety: MR-Buster, } \\
\text { Sunflower hybrid: Hysun-39 }\end{array}$ & $\begin{array}{l}\text { Weed management } \\
\text { through } \\
\text { intercropping }\end{array}$ & $\begin{array}{l}\text { Intercropping of both sorghum } \\
\text { and sunflower in cotton was } \\
\text { effective in weed management }\end{array}$ & {$[33]$} \\
\hline 28. & $\begin{array}{l}\text { Sorghum hybrid } \\
\text { (46 genotypes) }\end{array}$ & $\begin{array}{l}\text { Find correlation } \\
\text { among yield of } \\
\text { sorghum hybrid } \\
\text { and its iometrical } \\
\text { characters }\end{array}$ & $\begin{array}{l}\text { Yield and plant population; } \\
\text { number of green leaves and } \\
\text { plant population; plant height } \\
\text { and yield were correlated }\end{array}$ & {$[29]$} \\
\hline 29. & Leaves of Sorghum & Leaf spot disease & $\begin{array}{l}\text { Pathogen identified } \\
\text { as Curvularia lunata }\end{array}$ & {$[32]$} \\
\hline 30. & Sorghum variety JS-2002 & $\begin{array}{l}\text { Effect of tillage } \\
\text { and mulching } \\
\text { practices on grain } \\
\text { yield and soil } \\
\text { fertility }\end{array}$ & $\begin{array}{l}\text { Reduced tillage operations and } \\
\text { poultry manure mulching is } \\
\text { suitable for improving soil } \\
\text { properties and grain yield of } \\
\text { sorghum }\end{array}$ & [34] \\
\hline 31. & Sorghum & $\begin{array}{l}\text { Influence if } \\
\text { organic materials } \\
\text { on growth and } \\
\text { phosphorus uptake }\end{array}$ & $\begin{array}{l}\text { use of different organic } \\
\text { materials improves sorghum } \\
\text { growth }\end{array}$ & {$[35]$} \\
\hline 32. & $\begin{array}{l}\text { Eight Sorghum genotypes: YSS-9, } \\
\text { YSS-10, YSS-17, YSS-10, YSS-98, } \\
\text { YSS-18, YSS-19, } \\
\text { YSS-32 }\end{array}$ & $\begin{array}{l}\text { Grain yield and } \\
\text { related traits }\end{array}$ & $\begin{array}{l}\text { YSS-9 proved as a dual- } \\
\text { purpose variety with } \\
\text { reasonable grain and fodder } \\
\text { yields }\end{array}$ & {$[37]$} \\
\hline 33. & $\begin{array}{l}\text { Ten genotypes of Sorghum: FS-08 } \\
\text { FSD-11 NOOR F-114 F-113 } \\
\text { NARC-11 AARI-10 AARI-08 FA-08 }\end{array}$ & Drought tolerance & $\begin{array}{l}\text { NARC- } 11 \text { and Sorgh-11 were } \\
\text { drought tolerant } \\
\text { F-114 was drought sensitive }\end{array}$ & {$[36]$} \\
\hline
\end{tabular}




\begin{tabular}{|c|c|c|c|c|}
\hline & Sorgh-11 & & & \\
\hline 34. & $\begin{array}{l}\text { SS 97-2 (S1), PARC-SS-1, No. 1500, } \\
\text { No. 1692, T-3-DADU, 1572-T, S-98- } \\
\text { 6, SS-95-4, No. 1761, No. 1542, No. } \\
\text { 1620, No. 1728, SP-1832, SS-97-10, } \\
\text { SS 98-3, No.1828 (2001), F-9806, R- } \\
\text { 19, No. 1623, BR-123, PARC-SV-2, } \\
\text { SS-95-RG, SS-95-RG and BMR- } \\
\text { RED UNI }\end{array}$ & $\begin{array}{l}\text { Yield and } \\
\text { morphological } \\
\text { traits }\end{array}$ & $\begin{array}{l}\text { No. } 1623 \text { showed higher stalk } \\
\text { yield while SS 97-2 (S1) give } \\
\text { highest grain yield }\end{array}$ & [38] \\
\hline 35. & $\begin{array}{l}\text { Nine sorghum varieties: Local } \\
\text { Tandojam, F-9902, F-9917, No. } \\
\text { 1863, JS-263, F-9909, Js-2002, Local } \\
\text { Quetta, Local D. I. Khan, Giza-3 }\end{array}$ & $\begin{array}{l}\text { Green fodder yield } \\
\text { potential }\end{array}$ & $\begin{array}{l}\text { Local Tandojam produced } \\
\text { highest green fodder yield } \\
\text { while } \\
\text { Giza-3 produced lowest yield }\end{array}$ & [39] \\
\hline 36. & Sorghum & $\begin{array}{l}\text { Phyto-remediation } \\
\text { of Lead, } \\
\text { Chromium and } \\
\text { Cadmium }\end{array}$ & $\begin{array}{l}\text { Application of } 5 \mathrm{mM} \text { EDTA } \\
\text { enhanced the uptake of heavy } \\
\text { metal }\end{array}$ & [40] \\
\hline 37. & Sorghum or sunflower water extracts & Weed management & $\begin{array}{l}\text { Dual Gold (herbicide) in } \\
\text { combination with sorghum or } \\
\text { sunflower water extracts is } \\
\text { effective weedicide }\end{array}$ & {$[41]$} \\
\hline 38. & Sorghum and sunflower & $\begin{array}{l}\text { Phytotoxic } \\
\text { potential on cotton } \\
\text { seedlings }\end{array}$ & $\begin{array}{l}\text { Sorghum showed superiority } \\
\text { over sunflower in allelopathic } \\
\text { efficiency }\end{array}$ & [42] \\
\hline
\end{tabular}

Research on biofuel production from Sorghum world wide

Sweet sorghum is an emerging, potential candidate to serve for biofuel production due to its vast adaptability, easy cultivation, and high yield potential. Intensive exploitation of its diverse germplasm in various breeding programs has led to improved syrup, grain and forage yield. Monk et al. [43] performed study on increasing yield of sorghum hybrid in USA. The study demonstrated that both stalk and grain of this crops can contribute in energy sector such as $60 \mathrm{Mg}$ ha-1 of fresh biomass can produce 5000 liters ha -1 of ethanol [43]. Another study explored potential of sorghum as a renewable energy resource, as six sorghum cultivars were assessed for fermentable sugar production by determining agronomic traits, physiological characteristics and yields in nine different locations of USA [44]. Total sugar yield was variable for different locations, ranging from $4 \mathrm{Mg}$ ha-1 to 10.7
Mg ha-1, whereas Hawaiian island contributed highest yield of sugar with 12 $\mathrm{Mg}$ ha-1. Furthermore, per these sugar yields theoretical ethanol production was ranged between $2129 \mathrm{~L}$ ha-1 to $5696 \mathrm{~L}$ ha-1. Sweet sorghum are high adaptable as compared to other tropical plants that makes them superior and exceptional source of fermentable carbohydrates in diverse regions [44]. Smith and Buxton [45] determined impact of various factors such as: nitrogen fertilizers, as well as irrigated and nonirrigated conditions of USA on sugar yield of sweet sorghum. Addition of Nitrogen fertilizers had minute effect on improving fermentable sugar production. Their finding showed average of 3100 to 5235 liters ha-1 of ethanol yield for 2 year, suggesting potential use of sweet sorghum as an energy crop [45].

Biofuels hold promising future in energy and transport sector to supply electricity and liquid fuels without any modifications in 
current infrastructure. Woods [46] studied the potential of sweet sorghum under available condition and resources of Zimbabwe. The finding suggested 60 tons of total fresh weight of sorghum yielding 45 tons of fresh stems contributed in 30001/h of anhydrous ethanol and 12.6 GJ of electricity. Furthermore, he suggested that sweet sorghum can contribute in region's electricity and liquid fuel by utilizing only $1 \%$ of the land for growth and processing of crop [46]. Monti and Venturi [47] evaluated performance of four monocultures of sorghum and wheat cultivars at variable doses of nitrogen fertilizers to determine net energy, and energy use efficiency. Sweet sorghum could contribute maximum $50 \%$ of net energy than wheat and fiber sorghum when grown in climatic conditions of Italy (Figure 1). These finding suggested that ethanol production can be maximized to $90 \%$ if dry matter and bagasse of crop is also used; otherwise contributed net energy ratio was low. Moreover, highest ethanol production is obtained from straw, and resulting in low percentage of ethanol if straw is not processed [47]. However, structural carbohydrates makes up lignocellulosic biomass on digestion and thus fermentation has high potential to produce energy per hector as compared to nonstructural carbohydrates that include sugar and starch. Murray et al. [48] demonstrated that energy yields can be maximized in sweet sorghum if grain and biomass related traits are targeted for improvement. They evaluated genetic basis of 31 traits involved in biomass yield in F1 generation of grain sorghum 'BTx623' and 'Rio' sorghum line, and identified 110 quantitative trait loci. Many structural and non-structural carbohydrate related QTLs were found co-localized with flowering time, height, and stand density-tillering. They identified separate genetic control for structural carbohydrates and for protein accumulation in stem, grain and leave that contribute in maximizing energy yields [48]. They further identified QTLs responsible for high yield, with altered composition of stem sugar and grain with no pleiotropic effects. For example, a QTL on chromosome 3 was responsible for $25 \%$ genetics variance for stem sugar concentration while remained disassociated with any grain QTL. This finding suggested that non-structural yield can be improvised by altering genetic potential of grain and stalk by opting for QTLs responsible for sweet and high grain traits. This strategy can develop feedstock with qualitative traits and high yield to counter energy and food crisis [49].

Zhao et al. [50] evaluated carbohydrates, biomass and calculated ethanol yield (CEY) of five sorghum cultivars in Beijing, China from the day of anthesis to 40 days after anthesis (DAA). Although, all cultivars differed significantly in dry biomass, and carbohydrate content; yet, hybrid as feedstock for bioethanol conversion was comparatively higher performer than other cultivars. The environmental conditions and harvest time also influenced carbohydrate content and biomass production that ultimately affects the ethanol yield. However, the CEY increased with increase in crop cultivation duration and after anthesis period due to elevated accumulation of carbohydrates [50]. Miller and Ottman [51] determined the effect of frequent irrigation on sorghum growth and ethanol yield. They depleted plant available soil water during pre-anthesis and post-anthesis stage of sorghum by $65 \%$ in Tucson, AZ, USA (Figure 1). The result suggested that frequent irrigation showed negligible impact on biomass and ethanol yield, whereas, water stress with $50 \%$ depletion reduced biomass per unit of water with no increase in sugar concentration or accumulation at harvest of sweet sorghum [51]. 
Wortmann and workfellows [52] evaluated sweet sorghum, corn, and grain sorghum for energy use efficacy, along with greenhouse gases (GHG) emissions and ethanol yield at seven different locations in Nebraska, USA. Grain crops showed $21 \%$ to $33 \%$ more calculated ethanol yield and net energy yield than sweet sorghum, although mean net energy yield of an earlier-maturing sweet sorghum cultivar was equivalent to grain crops. The total energy utilized to convert grain crops to ethanol was $23 \%$ lower than that utilized on sweet sorghum. However, sweet sorghum and grain crops reduced GHG emissions by $69 \%$ than gasoline. The byproducts of grain crops during ethanol production were utilized efficiently, while sweet sorghum bagasse were returned to field as soil fertilizers. Sweet sorghum cultivars are competitive candidates for producing biofuel, but not as liquid transportation fuel as grain crops performed better [52]. Economou et al. [53] demonstrated conversion of sweet sorghum into biodiesel via oleaginous fungus $M$. isabellina in Greece. The fungus effectively converted sugar and nitrogen in sweet sorghum directly into storage lipid. The process was performed on semi-solid fermentation that had certain advantages like high quality oil-compared to liquid and solid state fermentation. Their findings concluded that lipid accumulation is possible due to nitrogen limitation allowing biomass growth and oil synthesis, whereas semi-solid state fermentation effectively extracted sugar from stem of sweet sorghum and lead to lipid accumulation [53].

Audilakshmi et al. [54] facilitated breeding of sweet sorghum for bioethanol purpose in relation to presence of high sugar content. They crossed $27 \mathrm{~B} \times$ BJ 204 (a Chinese line) and $27 \mathrm{~B} \times$ kellar (a US sweet sorghum line) to find generation mean and frequency distribution of useful traits during 2006 and 2007 in India. They reported that mean performance of F1 generation comprised of high brix and sucrose content (due to Parent 2 having high sugar percentage). In F1 generation: stalk, juice yield and plant height were marked as over dominant traits. In F2 generation sucrose percentage and Brix were found polygenic traits, although, juice and stalk were marked as oligogenic. These dominant and over-dominant traits were utilized in hybrid breeding programs to enhance production of bioethanol [54]. Sweet sorghum hybrids vary with respect to biomass yield and variable level of nitrogen that ultimately affect quality of extracted juice. Mosalia et al. [55] determined the impact of varying levels of nitrogen fertilizers on biomass, juice yield, and forage and bagasse quality in USA. Sorghum varieties harvested and evaluated at soft dough stage for required traits, showed increase in forage and juice yield due to fertilizers [55]. Guigou, et al. [56] studied effects of post-harvest conditions on three sweet sorghum varieties (M81, Topper and Theis) used for bioethanol production. Juices were obtained by milling whole plant, stalk and plant without panicle. Linear relationship was found between Brix degree and fermentable sugar concentration. Fermentable juice of sweet sorghum differed with respect to extraction treatments, yet showed similarity in fermentation efficiency and sugar concentrations. Theis and Topper varieties were superior in terms of ethanol yield, concentration and fermentation efficiency. Furthermore, post-harvest techniques and selection of desirable variety played critical role in bioethanol production from sorghum [56].

Sweet sorghum is widely cultivated as summer crop due to high resistance to salinity, while being productive through drought and during limited water resources. Vasilakoglou et al. [57] conducted a research in Greece to access the productivity of grass sorghum Susu as well as, sweet 
sorghum varieties, Sugar graze, M-81E, Urja and Topper-76-6, alpng with grain sorghum cultivar $\mathrm{KN}-30$ in terms of biomass, total fermentable sugar, juice and ethanol yield. The cultivars were grown in high saline conditions with low to intermediate water for irrigation. Sugar graze and Urja cultivars were high ethanol producing varieties with high juice content, for ethanol production when grown in saline soil and 50-75\% irrigation [57]. $\mathrm{Xu}$ et al. [58] demonstrated photosensitive sorghum (PS) grown in fields of USA, has great potential for bioethanol production due to high yield, drought tolerance, better sugar content and high biomass. Variable concentrations $(0.5$ to $1.5 \%$ ) of diluted sulfuric acid were used as pretreatment to hydrolyze cellulose for ethanol yield. and highest glucose yield of $80.3 \%$ was obtained with $1.0 \%$ of acid. The efficiency of hydrolysis increased up to $94.4 \%$ as the acid concentration rose up to $1.5 \%$ due to high degradation of available cellulose. Their findings reported $74.5 \%$ of ethanol yield due to above mentioned processing conditions, where $1 \mathrm{~g}$ of sorghum produced $0.2 \mathrm{~g}$ of ethanol [58]. Similar study conducted by Zhang et al. [59] produced butanol from sweet sorghum bagasse via acetic acid treatment to hydrolyze hemicellulose-rich biomass using Clostridium acetobutylicum ABE080-an acetic acid resistant strain. Hemicellulose hydrolyzed by $2 \mathrm{~g} / \mathrm{l}$ of acetic acid at $121 \mathrm{oC}$ for 10 minutes produced various compounds such as: carbohydrates, furfural, organic acid, hydroxymethyl furfural (HMF) and phenolics. Detoxification process with laccase eliminated phenolic compounds that were generated as by-products and served as primary inhibitors in hydrolysate step resulted in $8.5 \mathrm{~g} / \mathrm{l}$ of butanol [59]. Ananda et al. [60] investigated the effect of drought and heat stress on glucose of sorghum grain at different phenological stages and also its subsequent impact on bioethanol production in USA. The abiotic stress had negligible impact on glucose levels from grains as compared to control, yet an increase in ethanol production, up to $4.5 \%$, was observed in flowering and seed-setting stage. However, the heat stress significantly reduced glucose content and bioethanol production by $9 \%$ in different seed filling stages. Thus, abiotic stresses adversely affected phenological stages of sorghum; ultimately reducing ethanol yield [60].

Sorghum is widely adapted around the world and serves as the most attractive feedstocks for liquid fuels, due to efficient conversion of $\mathrm{CO} 2$ into sugar units. A study conducted in USA evaluated use of sweet sorghum in biofuel production [61]. Their research reported that sweet sorghum comprised of $37 \%$ juice, $36 \%$ bagasse, $19 \%$ leaf and $8 \%$ seed head, all of which can be utilized in producing bioethanol via Saccharomyces cerevisiae. Around $229.8 \mathrm{Kg}$ of carbohydrates from 1ton of sorghum can produce $59 \mathrm{~kg}$ of ethanol [61]. Qureshi et al. [62] evaluated production of ethanol from sweet sorghum grains and thereby sugar tolerance in Saccharomyces cerevisiae in Pakistan. Sorghum varieties were simultaneous saccharificated and fermented to produce ethanol from starch grains. The findings revealed that $S$. cerevisiae can tolerate $25 \%$ glucose and $11 \%$ ethanol. Separate hydrolysis and fermentation showed $95 \%$ fermentation efficiency in ethanol production, whereas, simultaneous saccharification and fermentation showed high concentration of ethanol [62].

Erickson et al. [63] focused on optimizing production of sweet sorghum using various management practices for bioenergy purpose. The effect of $\mathrm{N}$-fertilizers' rate on biomass, sugar yield, brix as well as $\mathrm{N}$ and $\mathrm{P}$ recovery were investigated for sweet sorghum in Florida, USA. N-fertilizers had no impact on biomass of sorghum, yet led to greater N-recovery and minor gain in sugar 
yield. The results suggested that proper management of nutrients can contribute in optimizing sugar yield in sweet sorghum for bio-based products [63]. Another study conducted by Holou and Stevens [64] determined optimum rate of $\mathrm{N}$-fertilizers in different soil materials (on silt loam, sandy loam, and clay soils) to produce high yield sweet sorghum at Missouri, USA. N-rate and soil material significantly affected juice yield by increasing sugar content (particularly due to $\mathrm{N}$-fertilizers). However, negative correlation existed between juice yield and sugar content of sweet sorghum. Sorghum displayed high sugar content when grown in silt loam compared to that in clay. Addition of $\mathrm{N}$-fertilizers in clay soil increased sugar yield of sweet sorghum, while in silt loam it displayed high sugar content only if cultured after corn. Significant difference existed in juice yield ranging 2-9.9 Mg/ha due to $\mathrm{N}$-rates, soil and other factors. Whereas, sorghum required low quantity of $\mathrm{N}$-fertilizers if planted after cotton or soybean. In general, $67 \mathrm{~kg}$ of $\mathrm{N}$ fertilizers were enough to optimize sugar, juice and bagasse yield [64].

Sambusiti et al. [65] demonstrated production of methane from five sorghum varieties via alkaline pretreatment in France. The samples were pretreated with $\mathrm{NaOH}$ in closed bottles for $12 \mathrm{~h}$ at $55 \mathrm{oC}$. The pretreatment reduced sorghum into lignin, cellulose, hemicellulose and galacturonic acids; thus further accelerating hydrolysis of cellulose and hemicelluloses. However, $\mathrm{NaOH}$ pretreatment was unsuccessful for increasing methane yields [65]. Rutto et al. [66] conducted a research on five sorghum varieties (Dale, M81E, Sugar Drip, Della and Keller) to evaluate quality of grain and juice as potential source of bioethanol in USA (see Figure no.1). Thus, stem weight and juice volumes were correlated ranging from 10 to $24 \mathrm{~m} 3 \cdot \mathrm{ha}-1$, though brix value ranged between 14-19\%. Yet, production of bioethanol from Keller and M81E was greater than theoretically estimated ethanol and sugar yields. The findings reported low grain, but high starch content in Keller than other cultivars being potential source for fermentable grain and sugar [66]. Martin et al. [67] demonstrated effective, high throughput method to screen feedstock toward biomass, cell wall digestibility, and fermentable sugar at 10 days post-anthesis for biofuel production in Australia. They designed a mathematical method along with high throughput strategy using fourth internode of plant to assess soluble sugar, stalk biomass, stalk fermentable sugar, and cell wall composition. The high throughput method using partial least squares (PLS) modeling measured soluble glucose, sucrose, and fructose in juice via Fourier transform infrared (FTIR) spectra. The findings showed sugar PLS correlated with brix and gas chromatography-mass spectrometry (GC-MS) [67].

Forage sorghum, Brown Mid-Rib (SBMR) and non-BMR (SNBMR) types, and sunn hemp (Crotalaria juncea L.) are widely used as fiber and forage crop in USA. Kamireddy et al. [68] evaluated these crops for biofuel purpose. The feedstock were treated with dilute acid and further by enzymatic hydrolysis cellulase. SNBMR showed highest xylose yield with $95 \%$ wt of xylose, than that of SBMR with 91 at combined severity factor (CSF). while sunn hemp showed maximum of $75 \%$ wt of xylose at CSF. On harsh pretreatment conditions, the amount of xylose decreases due to degradation. Similarly, after enzymatic hydrolysis glucan saccharification yield was highest in SNBMR with 90\% wt, while SBMR showed $84 \%$ wt, and Sunn hemp showed $68 \%$ wt at CSF. They concluded that SBMR and SNBMR can serve as potential candidate for biofuel production due to less crystallinity than Sunn hemp [68]. 
Recently, biofuel research has been accelerated in Pakistan due to scarcity of resources (Figure 1). Lignocellulosic biomass is pretreated to convert complex it into simpler substances for hydrolysis and fermentation. Sorghum bicolor straw potential lignocellulosic feedstock was evaluated for various pretreatment conditions (Acid concentration, Time and Temperature) in Pakistan. Samples were analyzed using HPLC, where maximum sugar value was observed with $2 \% \mathrm{H} 2 \mathrm{SO} 4$ at $121 \mathrm{oC}$ for 10 minutes, suggesting that optimized pretreatment conditions were effective prerequisite for production of bioethanol [69]. In India, Rao et al. [70] compared sorghum hybrids with open pollinated varieties (OPVs) for various quality related traits to produce potential bioethanol and high yielding grains. Sixteen genotypes were evaluated for sugar and stalk related traits. Stalk yield from sorghum hybrids and OPV ranged between 29.4 to $46.5 \mathrm{t}$ ha-1, while grain yield was recorded higher for hybrids than OPVs. SPSSV30 showed highest total soluble sugar and juice Brix. Among hybrid group genotypes,: SPSSH 24, SPSSH 27, PAC52093, whereas among OPV genotypes: SPSSV 20, SPSSV 27 and SPSSV 15, showed superior bioethanol and total sugar yields. Hybrids can support energy sector due to10-18\% high production of stalk biomass and bioethanol yields compared to OPV [70].

Sugarcane has served as renewable alternative source to solve energy crisis in developed countries, though, after paying heavy price of using agricultural land, nutrients and water. Recently, the research has been shifted toward use of sorghum cultivars as an alternative source of energy due to its high adaptability, resistance and limited use of water making it an excellent candidate. Dutra et al. [71] evaluated bioethanol production from eight sorghum cultivars developed in state of Pernambuco,
Brazil. The cultivars were pretreated, then fermented by $S$. cerevisiae, at 33oC for 6 hours. Sorghum cultivars SF 15 showed highest bioethanol potential, followed by BR 506 [71].

Theuretzbacher et al. [72] evaluated three sorghum varieties for bioethanol and biogas synthesis and compared the outcomes with a maize variety. One grain variety " $\mathrm{C}$ " (Chopper), and two sweet sorghum varieties "SG1" (Sugargraze I) and "SG2" (Sugargraze II) were grown in eastern Austria. The varieties were analyzed for sugar content and composition to determine sorghum potential to produce biofuel. SG1 and $\mathrm{C}$ varieties showed highest and improved energy output than maize. Furthermore, biogas and bioethanol production was variable in among sorghum varieties due to difference in sugar and starch. Variety $\mathrm{C}$ provided $54 \%$ bioethanol and $46 \%$ methane, while SG1 contributed in $30 \%$ bioethanol and $70 \%$ methane [72]. Lignocellulosic biomass are converted into bioenergy based products via various pretreatment and fermentation strategies. A study conducted by Vandenbrink et al. [73] investigated crystallinity index trait, and feedstock composition of twenty sorghum varieties grown in USA. They performed enzymatic hydrolysis (using Aspergillus niger cellulases and Trichoderma viride) on sorghum to obtain high sugar yield. The study illustrated positive correlation of hydrolysis yield potential with stem (due to presence of lignin content) as well as negative correlation due to crystallinity index. Thus, sorghum leaf showed negative correlation for hydrolysis due to absence of lignin. However, each genotype efficacy was variable with respect to pretreatments (ammonium hydroxide and $T$. viride cellulose). These pretreatment factors can be optimized to obtained bioethanol in largescale. Similarly, butanol synthesis were positively correlated with stem tissues, while 
suggesting that selection of genotype with high ratio of stem to leaves can improve end product yield [73].

Cotton et al. [74] studied biomass and cellulosic properties of forage sorghum differed on basis of brown midrib trait (i.e., bmr12) to produce ethanol under limited irrigation, while comparing to dry land (no irrigation) conditions of Southern High Plains of the USA (see Figure no.1). The Sorghum Partners 1990 produced highest biomass under irrigated and dry land conditions, yet, PaceSetter bmr showed highest cellulosic efficiency on simultaneous saccharification and fermentation to produce bioethanol. The study demonstrated that irrigation can increase up to $49 \%$ of biomass and $72 \%$ of cellulose for bioethanol production compared to limited irrigation (had no effect on biomass and biofuel production). The findings concluded that low precipitation did not affect the cultivars, while high precipitation increased cellulose by $28 \%$ in sorghum Partners 1990 that further amplified bioethanol production. The results showed that precipitation and irrigation were crucial factors that directly impacted biomass and biofuel production [74]. Mehmood et al. [34] evaluated four varieties of sorghum (84-Y-01, 85-G-86, Mr. Buster and RARI S-3) to unleash their use as ideal feedstock for bioethanol production in Pakistan. The straw of sorghum varieties were pretreated with diluted sulfuric acid and enzymatically hydrolyzed to ensure complete sugar extraction and conversion to bioethanol. Their study assigned following sequence to sorghum varieties with respect to sugar yield: 85-G-86>Mr. Buster> 84-Y-01 > RARI S-3. Nevertheless, variety (85- G-86) was considered ideal feedstock due to low by-products, furans and high sugar yield [34]. Similar study was conducted by Dalla Marta et al. [75] to examine sorghum growth at different developmental stages under constant water stress in Italy. They determine its potential use as first and second generation biofuel. The study concluded that duration of growth and cultivation period should depend on objective of use. Such as, if the target is bioethanol production, then longer duration for cultivation period was suitable, on the contrary, flowering stage was considered suitable harvest time to address optimal use of water [75]. Another study was performed in Guatemalan Pacific coastal plains on six varieties of sorghum to evaluate sugar potential in stem for bioethanol and nutritional value from grains. Of all varieties Top 76-6 variety was found exceptional in both terms of grain nutrition and high sugar value in stem with capacity to produce 2465 1 ha- 1 of ethanol. Grains had $83.2 \%$ of digestible proteins and low level of polyphenols [76]. Sweet sorghum was investigated as an alternate feedstock for bioethanol by Embrapa (Brazilian Agricultural Research Corporation of Maize and Sorghum). Fernandes et al. [77] used juices of 4 four sorghum varieties (BRS 506, BRS 508, BRS 509, BRS 511 and BRS) and evaluated their nutritional contents including, sugar, starch and respective theoretical ethanol yield. The study concluded that three varieties (BRS 508, BRS 509 and BRS 511) were potential candidates for bioethanol as their maturity exceeds 30 days. The nutritional value in sorghum varieties decreases with increase in cultivation duration. BRS 511 showed highest sugar production, whereas BRS 508 yielded $90.5 \%$ theoretical bioethanol within 8 hours of fermentation, which is similar to bioethanol produced from sugarcane juice [77].

Cuevas et al. [78] agronomically evaluated 925 accessions (originally belonged to different countries and compared them with accessions of USA) obtained from U.S. National Plant Germplasm System (NPGS). 
They evaluated physiological parameters, morphological parameters, fermentable sugar, juice volume, brix values, and disease responses toward rust (Purcina purpurea) and anthracnose (Colletotricum sublineolum). The findings concluded that nine accessions belonging to Ethiopia, South Africa, Sudan, Zimbabwe showed high brix values than accessions belonging to USA. Similarly, dry mass of accessions belonging to Ethiopia and USA were higher than reference number of other countries. New sources of rust and anthracnose disease resistance were identified, while accession from Tanzania was found resistant to both diseases. The findings showed that NPGS sorghum collection consisted of valuable germplasm that can be exploited in breeding programs to fulfill biofuel purpose paving integration of such germplasm in genetic diversity and new varieties for bio-based products [78]. Mocoeur et al. [79] crossed sweet and grain kaoliang sorghum to obtain recombinant inbred lines to find genetically stable biomass, as well as morphological and biofuel related traits in field trials conducted in Denmark and China. They determined 53 QTLs using PAV markers (presence and absence variant) from which 18 QTLs were common for both countries. However, out of 15 traits only eight were genetically stable and heritable. Plant height was positively correlated with biomass, whereas juice and brix content were negatively correlated. In Denmark trials sheading stage was correlated with biomass and morphological traits. QTLs for maturity identified on two chromosome of SBI01 and SBI02 were associated with early chilling tolerance; suggesting that accelerating maturity built the tolerance to low temperature. The finding also suggested that selection of sorghum on basis of early maturity, plant height, and high Brix content can contribute in bioenergy and biofuel alternative for Northern Europe [79].
Sweet sorghum is considered analogous to sugarcane due to sugar accumulation, Brix content, and lignocellulosic residues (pretreated to obtain sugar for ethanol). A study was conducted in Kenya on 16 sweet sorghum bagasse, which could be sustainable source of biofuel [80]. Sweet sorghum bagasses were dried and pretreated with alkaline hydrogen peroxide and phosphoric acid to yield $63.40 \%$ and $49.12 \%$ of glucose. Further hydrolysis and fermentation of bagasse by Trichoderm reesei via cellulose enzyme produced $88 \%$ (treatment with sodium hydroxide) and $77 \%$ (treated with phosphoric acid) of sugar yield. The study suggested that bioethanol can be produced from sorghum bagasse to widen the scope and strength of bioenergy sector [80]. Similarly, Khalil and his colleagues [81] analyzed productivity and biofuel related traits from bagasse of five sweet sorghum varieties in Egypt. Tested varieties differed in juice content, bagasse and stalk yield. Extracted juice was fermented by Zymomonas mobilis ATCC 29191 and Saccharomyces cerevisiae ATCC 7754 to produce bioethanol. Three sorghum varieties were squeezed directly to obtain juice while Ramada, Mn-1054, and SS-301 rich in fiber had to be pretreated with $2 \%$ $\mathrm{H} 2 \mathrm{SO} 4(98 \%)$ at $120 \mathrm{oC}$ to extract juice from sugar rich filtrate for bioethanol production. The finding showed that mixedcultured treatment can help to obtain highest juice such as: $1 \mathrm{Kg}$ of SS-301 variety produced $160 \mathrm{~mL}$ of bioethanol from juice and bagasse [81].

Biofuel from crops not only reduces our dependency on depleting fossil fuel but also lowers $\mathrm{CO} 2$ emission in environment. Currently, bioethanols are commercially available and used in certain percentages with gasoline in developed countries like USA, and Brazil. Therefore, production of bioethanol depends on agricultural land, crop production, resources, as well as 
governmental and social policies. Xuan et al. [82] evaluated optimum time required for sowing sorghum seeds and determined suitable cultivation condition required to obtain maximum yield for biofuel production in Vietnam. Suitable cultivation conditions to obtain $>5000 \mathrm{~L}$ ha-1 yield of ethanol were $5.5 \mathrm{pH}$, along with $\mathrm{Al}$ and $\mathrm{Zn}$ content ranging between 39.4 and $0.6 \mathrm{~g}$ $\mathrm{kg}-1$. $\mathrm{pH}$ higher than 6.0 can reduce biomass and bioethanol yield through altering $\mathrm{Zn}$ content, however, other minerals like $\mathrm{P}, \mathrm{N}, \mathrm{K}$, Organic $\mathrm{C}$, and $\mathrm{Fe}$ are less likely to contribute in biomass. Their finding recommended that cultivar 4A can highly contribute in ethanol production due to it high resistance toward peat diseases especially cut worm (Agrotis spp) [82]. Maw et al. [83] tested the effect of $\mathrm{N}$ fertilizers on dry mass, stem juice yield, sugar yield, theoretical ethanol juice, lignocellulosic ethanol yield, and total ethanol yield from two sorghum varieties (Dale and Top 76-6) grown in Missouri,
USA (see Figure no.1). N-fertilizers failed to show significant impact on brix content; yet, other parameters were highly influential in both varieties, though. highest ethanol yields was obtained with $168 \mathrm{~kg}$ ha-1 of $\mathrm{N}$ fertilizers. Whereas low temperature and high precipitation levels were also important factors to contribute in ethanol yields [83].

Mengistu et al. [84] determined water use efficiency for sweet sorghum and its impact on biofuel production under two different climatic conditions of South Africa (Hatfield and Ukulinga research farm). Theoretical ethanol production was calculated through Brix \% produced as well as stalk yield. The findings concluded that sweet sorghum has variable water use efficiency (WUE) under different climatic conditions, such as Hatfield produced maximum of 0.70 L-m-3 of ethanol, which was comparatively higher than that from Ukulinga research farm. Therefore, WUE of sweet sorghum was considered sensitive to plant density [84].

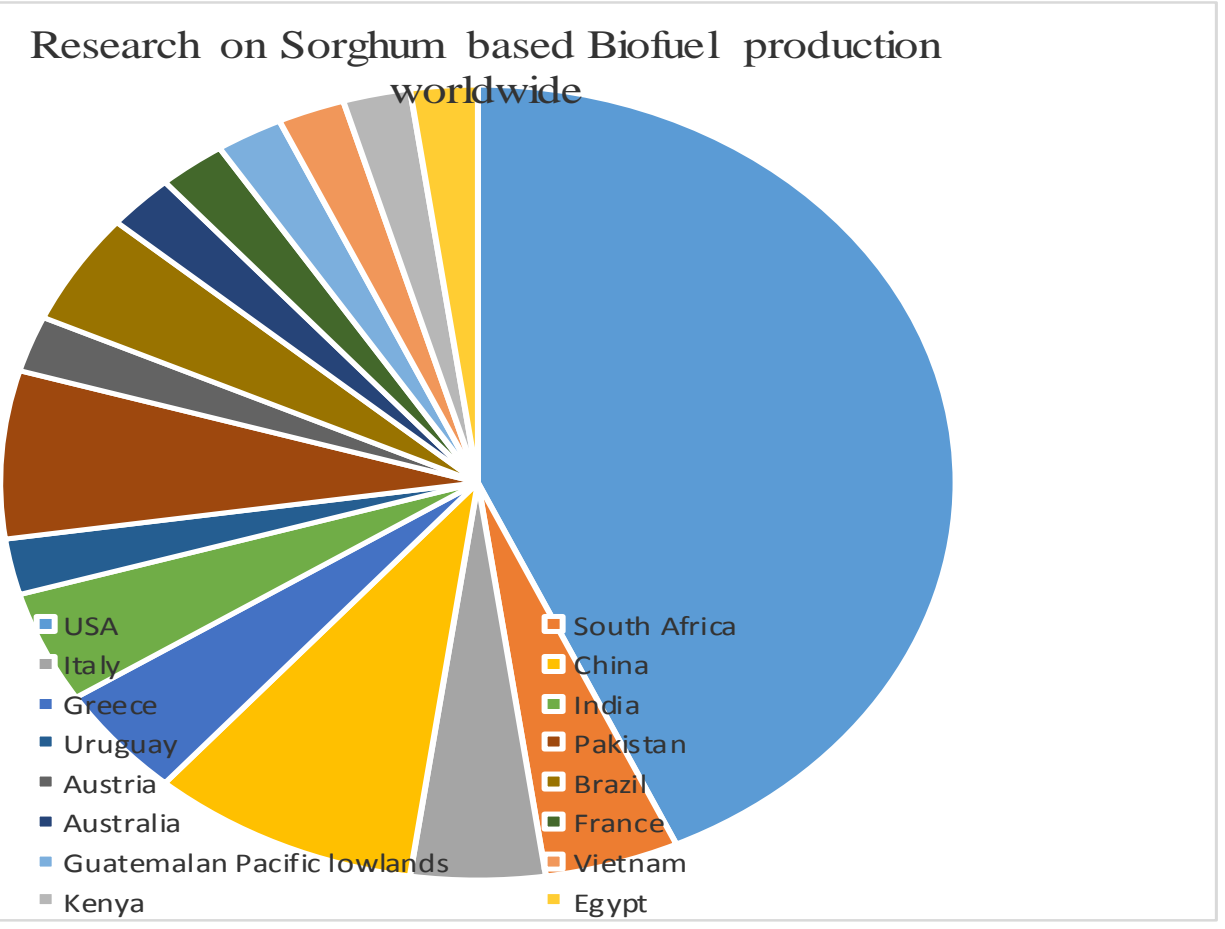

Figure 1. Biofuel production from sorghum worldwide 


\section{Role of microRNA in biofuel production in different crops}

MicroRNA (miRNA) plays important role in development and stress resistance of plants via post transcriptional gene regulation. miRNA are small RNAs that are usually 21 $22 \mathrm{nt}$ long, and produced in series from splicing action of RNAse-III like enzyme Dicer on its precursors with short hairpinloop structures [85]. miRNA are negative regulators of gene expression and act by splicing or inhibiting the target mRNA for protein translation [86]. Keeping function of miRNA in view, many novel miRNAs has been identified and further identification is a key to unravel the mechanism of stress tolerance.

Cultivation of Brachypodium, Miscanthus and switchgrass are emerging with broad scope in bioenergy field. Switchgrass is center of attention worldwide due to its wide adaptability to grow, and tolerate drought spells. However, the basis of genome responsible for such traits is still unexplored. Recent research shows that microRNA are responsible for gene expression in growth, development and adaptation to wide range of circumstances (Table 2). Matts et al. [87] identified miRNA families in switchgrass responsible for growth and development with tissue-specific expression, and ubiquitous expression in some species. The findings showed expression of miR395 and miR399 under optimal level of sulfate and phosphate, and slightly altered under phosphate and sulfate deficit conditions. They suggested 4 target mRNA like NAC domain containing transcription factor, apetala 2-like, Squamosa promoter bindinglike factor, and HD-Zip homologs and 37 genes as targets for miRNA [87]. Similar study performed by Xie et al. [88] identified 121 miRNA in switchgrass belonging to 44 families using comparative genomics approach. These miRNA targeted 839 proteins coding genes and played important role in biological, metabolic processes and plant development. Whereas gene ontology showed that miRNA has crucial role in 527 biological processes on the basis of these targets. Among these processes, 23 processes are involved in metabolic activities of carbohydrates, lipids and xylem formation. The findings analyzed 118 metabolic pathway networks involved in oxidative stress response, hormone regulation, carbon fixation, metabolism of fat and sucrose and other secondary metabolites [88].

Zanca et al. [89] reported 19 sugarcane miRNA precursors responsible for high bioethanol yield in sugarcane and found similar to sorghum at nucleotide and secondary structure levels (Table 2). Mature miRNA can be accumulated in specific tissues and organs of sugarcane. The findings determined 46 potential targets for 19 miRNA of sugarcane several targets of conversed miRNA were involved in plant development as transcription factors. The findings classified 19 miRNA precursors in sugarcane and one miRNA precursor in sorghum into 14 families. Comparative analysis of sugarcane with sorghum showed common homologous miRNA and their targets in genome of these two species. Hence, such conservation may help to clarify specific aspects of miRNA regulation and evolution in the polypoid sugarcane [89].

Foxtail millet (Setaria italica) belongs to poaccace family and is widely used as food, fodder and as model crop for biofuel grasses. Zhang et al. [90] drafted genome onto nine chromosomes and annotated 38,801 genes. The findings demonstrated that reshuffling events of foxtail, sorghum and rice contributed in divergence of the crops. Two reshuffling events of key chromosomes were identified via collinearity between 2 and 9 chromosome of foxtail millet with $3,7,9$, and 10 
chromosomes of rice that occurred after divergence of foxtail and rice. Single reshuffling event occurred between foxtail millet chromosome 3 with rice chromosome 5 and 12, after divergence of sorghum and millet [90]. Recent study showed genetic improvement of switchgrass biomass to develop emerging bioenergy crops. miR 156 precursor was overexpressed in switchgrass and its effect on squamosa promoter binding protein like (SPL) genes were determined via microarray and RT-PCR. The findings characterized biomass yield, forage digestibility, saccharification efficiency and morphological alterations. miR156 overexpression suppresses SPL gene and is associated with apical dominance and transition in flowering time; while, low expression of miR156 was sufficient to increase biomass with normal flowering time, and disruption of apical dominance. Moderate expression of miR156 improved biomass, yet inhibits flowering. Thus, low and moderate expressions contribute in $58 \%-101 \%$ high biomass yield, though high miRNA expression result causes stunted growth (Table 2). Consequently, the degree of morphological alterations depends on level miR156 expression. High expression enhances solubilized sugar yield, forage digestibility and biomass yield by increasing tiller number [91].

Switchgrass dedicated biofuel crop is broadly cultured for its high adaptability for marginal lands and high biomass yield. However, limited knowledge is available on basic mechanism of its gene expression under stressful conditions. Study conducted by Sun et al. [92] demonstrated expression of regulatory miRNA on physiological parameters under salt and drought stress. The finding indicated that $1 \%$ salt stress adversely effected germination rate and growth, whereas, drought stress showed slight impact on germination. The miRNA expression of switchgrass under salt and drought stress was dose-dependent, and upregulated the gene expression by 0.9 folds and downregulated by 0.7 folds. Though, miRNA under both stresses showed similar range of expression yet, miRNA were more sensitive in drought stress, as miR156 and miR162 displayed significant expression, suggesting role of miRNA to cope up with drought stress (Table 2). Therefore, transgenic lines can improve bioenergy crops for biofuel production [92]. Drought spells are widely known to reduce the yield of majority crops. Certain genes are expressed to plant cope up with drought stress and manage water, yet this mechanism remains unexplored in majority of crops. Ferreira et al. [93] conducted a study to explore expression of miRNA in two cultivars of sugarcane under drought stress. Sugarcane cultivar RB855536 known for low drought tolerance and RB867515 cultivar with high tolerance were grown for 3 months and subjected to drought stress for 2-8 days. The results revealed identification of 18 miRNA families via deep sequencing, out of which 7 miRNA were differentially expressed in drought stress. Furthermore, differential expression of miRNAs depends on duration of stress, such as 6 miRNAs were differentially expressed after 2 days and 5 miRNA were expressed at 4 days of stress [93].

Brachypodium distachyon belongs to Poaceae family and known to produce biofuel. Jeong et al. [94] sequenced 17 small RNA libraries and identified miRNA populations representing diverse stress conditions and tissues. The study identified 115 miRNAs using computational tools, which included conserved, non-conserved and novel miRNA. PARE (Parallel Analysis of RNA Ends) based identification of miRNA cleavage function were used to construct PARE libraries. The PARE libraries constructed from key tissues resulted in $\sim 70$ million raw sequences and 
$\sim 5$ million genome matched sequences. PARE data analysis of miRNA mediated cleavage represented 250 sites involved in miRNA targets. Furthermore, characterization of target sequences and miRNA in Brachypodium were involved in tissue-preferential control of miRNA family members, responsible for differential target cleavage. The PARA data from other crops and Brachypodium provided insight on role of miRNA and its target regulation to exploit various features to fulfill biofuel purpose [94]. Another study performed by Green [95] identified genome wide targets of miRNA in Arabidopsis using PARE analysis and applied PARE further to Brachypodium distachyon genome. The findings suggested identification of new miRNA and regulations with respect to environmental stresses and type of tissue. 260 targets of miRNA were identified using PARE sequences were responsible for precise miRNA guided cleavage. PARA analysis revealed that differentially expressed miRNA guide is responsible for specific target RNA cleavage in tissuepreferential manner miRNA-target RNA regulation. Therefore, specific miRNA targets RNA association with known physiological functions, providing insight on gene regulation and response under environmental stresses in different tissues [96]. Recently, genomic tools are used to exploit lignocellulosic synthesis genes to harness high yield of biomass, however, the lack of complete genome in majority of bioenergy grasses hinders the study on crop improvement. Muthamilarasan et al. [97] studied foxtail millet and identified gene families responsible for monolignol biosynthesis (PAL, C4H, 4CL, HCT, C3H, CCOAOMT, F5H, COMT, CCR, CAD), callose (Gsl) and cellulose (CesA/Csl). Comparative analysis of lignocellulose biosynthesis genes of foxtail millet with genome of $\mathrm{C} 4$ crops showed high resemblance with switchgrass followed by sorghum and maize. Whereas, expression profiling revealed that lignocellulosic gene was differentially expressed under abiotic stresses and hormonal treatments. The results suggested that monolignol biosynthesis proteins were highly diverse, while Gsl and CesA/Csl proteins were homologous to Oryza sativa and Arabidopsis thaliana [97]. Furthermore, lignocellulosic crops faces economic barrier during biofuel production due to cell wall recalcitrance. Many researchers are actively working to explore genes that can offer solution to fix this problem via genome wide study. miRNAs are known to be involved in all biological, developmental and metabolic processes due to broad functions of their targets. Alteration in miRNA expression can lead to pleiotropic effects. Such as miRNA regulates physiological and biological traits such as low expression of miR156 increases biomass and reduces recalcitrance, while high expression of miRNA in bioenergy switchgrass and poplar reduces lignin content, increase biomass and flowering time with improved responses toward harsh environment [98]. 
Table 2. Role of miRNA in crops for biofuel production

\begin{tabular}{|c|c|c|c|c|}
\hline S No. & Crop & No. of miRNA & miRNA & Refs. \\
\hline 1. & $\begin{array}{l}\text { Switchgrass } \\
\text { (Panicum virgatum } \\
\text { L.) }\end{array}$ & $\begin{array}{l}20 \text { conserved miRNA } \\
\text { families. } 37 \text { genes were } \\
\text { predicted as targets for } \\
\text { miRNAs and } 4 \text { target } \\
\text { mRNAs }\end{array}$ & $\begin{array}{l}\text { miR156a,b, miR156e, miR156f, miR156k, } \\
\text { miR159b, miR160, miR164a, miR164c, } \\
\text { miR166, miR167b, miR168, miR169a, } \\
\text { miR169c, miR169d, miR169b, miR169k, } \\
\text { miR171g, miR172a, miR172c, miR172b, } \\
\text { miR172d, miR319, miR393, miR394, } \\
\text { miR395n, miR396n, miR397, miR398n, } \\
\text { miR399, miR408, miR437, miR444, miR528 }\end{array}$ & [87] \\
\hline 2. & Switchgrass & $\begin{array}{l}121 \text { potential miRNAs, } \\
\text { belonging to } 44 \text { families }\end{array}$ & & {$[88]$} \\
\hline 3. & $\begin{array}{l}\text { Sugarcane } \\
\text { (Saccharum spp.) }\end{array}$ & $\begin{array}{l}19 \text { miRNA precursors } \\
\text { a total of } 46 \text { potential } \\
\text { targets for } 19 \text { sugarcane } \\
\text { miRNAs }\end{array}$ & $\begin{array}{l}\text { miR156a, miR159a, miR167a, miR168a, } \\
\text { miR169, miR396a, miR827, miR408a, } \\
\text { miR437, miR444, miR528, miR1128, } \\
\text { miR1432, miR319b }\end{array}$ & [89] \\
\hline 4. & $\begin{array}{l}\text { Foxtail millet } \\
(\text { Setaria italica) }\end{array}$ & $\begin{array}{l}\text { Seven homologues of } \\
\text { miRNA }\end{array}$ & miR169g & {$[90]$} \\
\hline 5. & Switchgrass & $\begin{array}{l}\text { miR156b precursor } \\
\text { overexpression improved } \\
\text { biomass, solubilized sugar } \\
\text { yield and forage } \\
\text { digestibility }\end{array}$ & $\operatorname{miR} 156 b$ & {$[91]$} \\
\hline 6. & Switchgrass & $\begin{array}{l}\text { miR156 and miR162, } \\
\text { showed significant change } \\
\text { in expression }\end{array}$ & $\begin{array}{l}\text { miR156, miR157, miR159, miR162, miR167, } \\
\text { miR169, miR172, miR395, miR396, miR397, } \\
\text { miR398, miR399 }\end{array}$ & {$[92]$} \\
\hline 7. & $\begin{array}{l}\text { Sugarcane } \\
\text { (Saccharum spp.) }\end{array}$ & $\begin{array}{l}\text { miRNAs differentially } \\
\text { expressed under drought } \\
\text { stress }\end{array}$ & $\begin{array}{l}\text { miR156, miR160, miR164, miR166, iR167, } \\
\text { miR169, miR171, miR172, miR319, iR390, } \\
\text { miR393, miR394, miR396, miR397, iR399, } \\
\text { miR528, miR529, miR1432 }\end{array}$ & [93] \\
\hline 8. & $\begin{array}{l}\text { Wild grass } \\
\text { Brachypodium } \\
\text { distachyon }\end{array}$ & $\begin{array}{l}116 \text { miRNAs conserved } \\
\text { and non-conserved } \\
\text { miRNAs }\end{array}$ & $\begin{array}{l}\text { miR5163b-3p, miR5181e, miR51851-3p.2, } \\
\text { miR7731, miR7738-3p, miR7754-3p, } \\
\text { miR9480ab, miR9481a, miR9481b, iR9482, } \\
\text { miR9483ab, miR9484, miR9485, miR9486a, } \\
\text { miR9486a, miR9486b, miR9487, miR9488, } \\
\text { miR9489, miR9490, miR9491, miR9492, } \\
\text { miR9493, miR9494, miR9495, miR9496, } \\
\text { miR9497, miR9498, miR9499 }\end{array}$ & [94] \\
\hline 9. & Wild grass & $\begin{array}{l}80 \text { new miRNA precursors } \\
\text { (conserved and non- } \\
\text { conserved) } \\
260 \text { targets of new and } \\
\text { known miRNAs with } \\
\text { PARE sequences at the } \\
\text { precise cleavage site were } \\
\text { identified and characterized }\end{array}$ & miR166, miR156, miR529, miR5163b-3p & [96] \\
\hline 10. & $\begin{array}{l}\text { Foxtail millet } \\
\text { (Setaria italica } \mathrm{L} . \text { ) }\end{array}$ & $\begin{array}{l}\text { Potential miRNAs target } \\
\text { few genes for post- } \\
\text { transcriptional gene } \\
\text { silencing }\end{array}$ & $\begin{array}{l}\text { miR156d-1, miR156d-2, miR395b, miR114- } \\
\text { npr, miRn29 }\end{array}$ & {$[97]$} \\
\hline 11. & Wild grass & $\begin{array}{l}\text { Metabolism, development, } \\
\text { stress response }\end{array}$ & $\begin{array}{l}\text { miR156, miR160, miR167, miR169, miR172, } \\
\text { miR397, miR398, miR414, miR5200 }\end{array}$ & {$[98]$} \\
\hline
\end{tabular}




\begin{tabular}{|r|l|l|l|l|}
\hline 12. & $\begin{array}{l}\text { Cassava (Manihot } \\
\text { esculenta) }\end{array}$ & $\begin{array}{l}\text { Metabolism, development, } \\
\text { stress response }\end{array}$ & $\begin{array}{l}\text { miR156, miR160, miR164, miR172, miR395, } \\
\text { miR482 }\end{array}$ & {$[98]$} \\
\hline 13. & Jatropha curcas & $\begin{array}{l}\text { Metabolism, development, } \\
\text { stress response }\end{array}$ & $\begin{array}{l}\text { miR004, miR156, miR172, miR395, miR398, } \\
\text { miR5201, }\end{array}$ & {$[98]$} \\
\hline 14. & Maize (Zea spp.) & $\begin{array}{l}\text { development, stress } \\
\text { response }\end{array}$ & $\begin{array}{l}\text { miR156, miR160, miR164, miR166, miR167, } \\
\text { miR169, miR172, miR319 }\end{array}$ & {$[98]$} \\
\hline 15. & $\begin{array}{l}\text { Poplar (Populus } \\
\text { spp) }\end{array}$ & $\begin{array}{l}\text { Metabolism, development, } \\
\text { stress response, Pathogen } \\
\text { response, Cold response }\end{array}$ & $\begin{array}{l}\text { miR156, miR159, miR160, miR164, miR166, } \\
\text { miR169, miR172, miR319, miR472, } \\
\text { miR1445, miR1446 }\end{array}$ & {$[98]$} \\
\hline 16. & $\begin{array}{l}\text { Sugarcane } \\
\text { (Saccharum Spp.) }\end{array}$ & $\begin{array}{l}\text { development, abiotic stress } \\
\text { response }\end{array}$ & $\begin{array}{l}\text { miR156, miR159, miR164, miR397, miR399, } \\
\text { miR28 }\end{array}$ & {$[98]$} \\
\hline 17. & $\begin{array}{l}\text { Switchgrass } \\
\text { biofuel yield, abiotic stress } \\
\text { response }\end{array}$ & $\begin{array}{l}\text { miR156, miR164, miR166, miR167, miR172, } \\
\text { miR398, miR414, miR444, miR477, miR528, } \\
\text { miR531, miR854, miR1535, miR1848, } \\
\text { miR2102, miR2118 }\end{array}$ & {$[98]$} \\
\hline
\end{tabular}

\section{Role of identified miRNAs in Sorghum}

Sorghum bicolor is well known staple crop in developing world and closely related to maize. It is desired crop due to high adaptability to wide range of climatic conditions, short production time, salinity and drought tolerance making it potential candidate for cultivation for biofuel production. Bedell ety al. [99] suggested that $95 \%$ of sorghum genes are sequenced tagged with $65 \%$ coverage across its length, generated sequence through hypomethylated portion of genome using methylation filtration (MF) technology. They studied functional parts of sorghum genome using MF technology to obtain information on miRNA, promoters, single sequence repeats, exons and introns, while minimizing interspersed repeats. MF based sequence is powerful source for comparative genomics with grasses and other important crops [99]. Previously, 286 miRNA genes clustered into 43 family has been identified in Arabidopsis, maize, and rice. Furthermore, Dezulian et al. [100] reported identification of 200 miRNA genes belonging to 43 families in genome of sorghum, maize, medick and poplar and expression of 37 miRNA precursors of sugarcane and soybean via computation tools. The study analyzed plant precursors such as: conserved precursors, secondary structure of miRNA and stem length. The findings suggested two classes of miRNA plant precursors. The abundant precursor class has strong conserved blocks that are corresponding to mature miRNA and its complementary sequence, while less frequent precursor class has two additional conserved blocks with long stem region and extensive secondary structure that includes miR159/319 and miR394 families [100]. miRNA are wide spread in all organism. Some miRNAs are highly conserved in plant species and linked to common ancestors in early evolution, with minute difference or absence of nucleotide substitution among plant species. Whereas, others potential miRNA are expressed and regulated under biotic and abiotic environmental stresses. Some miRNA are tissue specific and expressed under developmental switching. Previously, 75 miRNA belonging to 14 families were identified. Zhang et al. [101] suggested that EST analysis can identify new miRNA, and its targets (Table 3). They predicted RNA secondary structure of 812 EST sequence and identified 338 new miRNA in 60 plant species. miRNA are present among plant species in abundance and involved in variety of developmental, signal transduction and 
environmental stresses that stimulate miRNA synthesis and regulation [101].

Zhang et al. [102] identified 481 miRNA of 37 families from 71 different plants via EST analysis. The research revealed that miRNA in some plants were clustered together polycistron suggesting similar expression and transcription. Number of miRNA identified were related to available EST instead of evolutionary relatedness to $A$. thaliana, indicating that conserved and phylogenetic relation are linked to presence and absence of miRNA. However, miRNA expression existed in early evolutionary stages of plant and remains functional for 425 million years. Many miRNA families are conserved among major plant lineages like: monocots, gymnosperms, mosses, and eudicots [102] (Table 3). Zhang et al. [103] performed genome wide analysis of miRNA genes in maize, and characterized their structure, evolutionary relatedness and expression. Using computational homology and secondary structure modeling approach about 150 genes of 26 miRNA families were identified and validated. Moreover, 68 miRNA precursors belonging to 18 families were highly conserved among several species of plants, depicting this class of genes have splice variation and similar sites for alterative transcription. Analysis of sequence variation in diverse maize inbred lines teosinte accessions suggested that evolution of flanking sequences are similar to other genes. Additionally, the research suggested that, duplicated miRNA genes undergo gene lost like protein coding genes with only $35 \%$ ancestral sites retained; though the retained number is higher than protein coding genes [103].

Paterson et al. [104] determined genomewide sequence of sorghum via shotgun sequencing. About $98 \%$ genes in chromosomal context were validated by physical genetic, and syntenic information. The study revealed that one-third of sorghum genome is genetically recombined having gene density and gene order similar to rice. About $75 \%$ of sorghum genome is larger than rice genome because of retrotransposon accumulation in recombinationally recalcitrant heterochromatin. However, repetitive DNA and genes were preserved since 70 million year ago, yet prior to sorghum rice divergence most of the duplicated genes had lost one member. Sorghum genome comprises 7\% sorghum-specific genes and $24 \%$ grass-related genes. Therefore, duplicated miRNA genes contribute in drought tolerance of sorghum [104]. Zhang and coworkers [58] sequenced small RNA library by identifying miRNAs in Sorghum. The findings revealed 13 novel miRNA, 7 conserved miRNA and 29 miRNA families similar to monocots. Differential expression of conserved and novel miRNA indicated diverse role of 125 genes. These miRNAs were involved in diverse processes, and provides insights on miRNA controlled process that can be manipulated to improve biomass and stress tolerance in sorghum [58].

Majority of biofuel producing crops like: sorghum, Miscanthus, switchgrass, sugarcane and corn belong to tribe of Andropogoneae. Sorghum has simple genome as compared to other species due to lack of additional rounds of whole genome duplication events, and contribute in possibility to generate high quality genome sequence of sorghum. The research characterized small RNA from grains, stems of sweet sorghum and F2 generation (derived from cross segregated for flowering time and sugar contents). Variation in expression of miR395 and miR172 were correlated with flowering time, whereas variation in expression of miR169 was correlated with sugar content of stems. Furthermore, due to genotypic differences in miR395* were expressed equivalently as 
abundant as miR395 in sweet sorghum though lacked expression in grain sorghum. The research predicted 7 new miRNA and 27 known miRNA from expression of 25 miRNA families in sorghum genome. The study validated small RNA sequences from the stem of sweet sorghum for previously predicted miRNA, depicting its role in flowering time and stem sugar accumulation [105]. Katiyar et al. [106] identified miRNA and its target genes from 1379 unique and known miRNA of 33 different crops via Genomic Survey Sequence (GSS) and EST using computational tools. They determined 37 miRNA of 10 miRNA families with 72 potential target genes. These predicted targets lay foundation to understand miRNA function and involved in plant development and growth [106] (Table 3).

MicroRNA are involved in gene expression and plays crucial role in environmental stresses and development. Thiebaut et al. [107] predicted small RNA via deep sequencing and discovered novel miRNA using bioinformatics tools that regulated, pathogen infections, drought and salt stresses in sugarcane. Using miRNA precursors in sorghum genome 623 new mature miRNAs were identified in sugarcane, from which 44 miRNA highly unique in their biological function. Sets of miRNA in sugarcane were known to target zinc finger protein, $\mathrm{Myb}$, and serine/threonine kinases. RPP2B protein and MADS-box transcription factor were involved in disease resistant protein and plant development, regulated by miRNA cleavage and DNA methylation. Comparative analysis of miRNA between monocots provides valuable insight on conservative miRNA and their targets in unidentified genome sequence of plants [107].

Sorghum is C4 plant with high water efficacy and high adaptability to semi-arid regions. Pasini et al. [108] evaluated physiological and molecular basis of sorghum genotype during drought response in "dry-down" experiment, where stress was determined by water potential in 4-leaf-old plants. 1205 genes were up-regulated due to drought stress and involved in carbon metabolism (NADP-ME), detoxification (CYPs, GST, AKRs), signal transduction (phosphoesterases, kinases, phosphatases), osmoprotection mechanisms (P5CS), regulation of transcription (bZIPs, MYBs, HOXs), and stability of protein membranes (DHN1, LEA, HSPs). The findings suggested differentially expressed genes responsible for upregulation of 4 miRNA families, whereas one family was downregulated during early phase of drought stress [108]. In another similar study, Katiyar et al. [109] constructed small RNA libraries to identify tasi-RNAs and drought-responsive miRNAs via next generation sequencing on drought susceptible (C43) and drought tolerant (M35-1) sorghum lines. Research showed that around 241 miRNA has been identified in sorghum and deposited in the miRBase. The research identified 526 novel miRNA and 97 conserved miRNA belonging to unique miRNA families from sorghum, out of which 97 were regulated by drought stress (49 down regulated, 32 up-regulated, and 14 miRNA depicted contrasting expression between genotypes). A maximum of 18 miRNA were differentially regulated in tolerant and sensitive genotypes under drought stress condition. Genotype dependent miRNA regulation under drought stress contributed in differential drought tolerance of sorghum genotypes. Around 1300 target genes related to conserved and novel miRNA were identified with specific role related to biological, cellular, metabolic, and development processes. Stress responsive miRNA, tasi-RNA and their respective targets identified via genomewide search can unravel genetic and 
molecular mechanism responsible to cope up with drought stress, thus providing a key role to improve stress response and biomass production in sorghum [109].

Recently, Sanousi et al. [110] studied regulatory mechanism of miRNA related to drought and salinity in sorghum. They studied expression profiling of small regulatory RNAs in pre- and post-flowering stages of six sorghum genotypes under drought and salinity stress using RT-qPCR. The findings suggested that miRNA expression profile was dependent on dosage, whereas each miRNA exhibited different expression in response to stress in all genotypes. Furthermore, the expression of following miRNAs: miR156, miR167, miR168 and miR399 were variable as compared to previous studies, which suggested adaptation of sorghum toward stresses. Therefore, using transgenic technology sorghum can be exploited to produce improved varieties [110]. Alternative polyadenylation (APA) and alternative splicing of pre-miRNA contribute in diversity of transcriptome, expression regulation and coding capacity of genome in eukaryotes. These transcriptomes are analyzed by second-generation sequencing technologies. Abdel-Ghany et al. [111] sequenced sorghum transcriptome and developed pipeline-Transcriptome
Analysis Pipeline for Isoform Sequencing (TAPIS) (tool used for iso-sequencing data analysis) to identify APA sites and fulllength splice isoforms. The findings suggested transcriptome-wide full-length isoforms over 11,000 novel splice isoforms and discovered more than 2,100 novel genes and 11,000 expressed genes of APA [111] (Table 3).

Small RNAs are responsible for various developmental processes, whereas miRNA expression is regulated by environmental stresses in plant species. Hamza et al. [112] determined the expression profile of 8 down-regulated miRNA in 11 elite sorghum genotypes under drought stress and watered conditions. Expression level of miR396 and miR398 was highest in all sorghum genotypes, yet high deregulation was observed in, miR166, miR167, miR168, miR393, miR396, miR397-5p. The study suggested that high gene expression profile in grain sorghum HSD3226 in well-watered conditions; shifted the expression profile under drought stress. N98 and Atlas - forage accession showed contrasting expression profile of miR397-5p under drought stress depicting active mechanism to tolerate drought stress. Moreover, the research provides knowledge on miRNA with potential to improve drought stress in other cereal crops [112].

Table 3. Role of miRNA in Sorghum

\begin{tabular}{|c|c|c|c|c|}
\hline $\begin{array}{l}\text { S. } \\
\text { No }\end{array}$ & Identified miRNAs' families & $\begin{array}{c}\text { miRNA } \\
\text { associated(biotic/abiotic } \\
\text { ) traits }\end{array}$ & $\begin{array}{l}\text { NGS/Bioinformatics } \\
\text { approach used }\end{array}$ & Refs. \\
\hline 1. & $44(85 \%)$ miRNAs identified in sorghum & DREB1-like proteins & $\begin{array}{l}\text { Methylation Filtration (MF) } \\
\text { Technology, bioinformatics }\end{array}$ & [99] \\
\hline 2. & $\begin{array}{l}\text { sbi-miR156a,b,c,d, miR157, miR159a,b, } \\
\text { miR165, miR166, miR168, miR169, } \\
\text { miR170, miR171, miR172 }\end{array}$ & $\begin{array}{l}\text { Biotic or abiotic } \\
\text { environmental stresses } \\
\text { and hormone signaling }\end{array}$ & $\begin{array}{l}\text { Bioinformatics tool (EST } \\
\text { analysis) }\end{array}$ & [101] \\
\hline 3. & $\begin{array}{l}\text { sbi-miR156a,b,c,d, miR159, } \\
\text { miR160a,b,c,d,e, miR164, miR164b, } \\
\text { miR166a,b,c,d,e,f, miR167a,b,c,d,e,f,g, } \\
\text { miR168, miR169a,b,c,d,e,f,g,h,i, } \\
\text { miR171a,b,c,d,, miR172a,b,c,d,e, }\end{array}$ & $\begin{array}{l}\text { conserved sequence } \\
\text { blocks }\end{array}$ & Bioinformatics tools & [100] \\
\hline
\end{tabular}


Hafsa Ali et al.

\begin{tabular}{|c|c|c|c|c|}
\hline & $\begin{array}{l}\text { miR319, miR393, miR394a,b, } \\
\text { miR395a,b,c,d,e, miR396a,b,c, } \\
\text { miR399a,b,c,d,e,f }\end{array}$ & & & \\
\hline 4. & $\begin{array}{l}\text { A total of } 481 \text { miRNAs, } \\
\text { miR156, miR172, miR319, miR396 }\end{array}$ & $\begin{array}{l}\text { evolutionarily conserved } \\
\text { miRNA families }\end{array}$ & Bioinformatics & [102] \\
\hline 5. & $\begin{array}{l}\text { miR156, miR159, miR160, miR162, } \\
\text { miR164, miR166, miR167, miR168, } \\
\text { miR169, miR171, miR172, miR319, } \\
\text { miR390, miR393, miR394, miR395, } \\
\text { miR396, miR397, miR398, miR399, } \\
\text { miR408, miR482, miR528, miR529, } \\
\text { miR827, miR1432 }\end{array}$ & $\begin{array}{l}\text { Involved in secondary } \\
\text { metabolic processes, } \\
\text { biological processes } \\
\text { including gene expression } \\
\text { and response to stimuli }\end{array}$ & $\begin{array}{l}\text { Next generation sequencing } \\
\text { Bioinformatics }\end{array}$ & [103] \\
\hline 6. & $\begin{array}{l}\text { miR156a,b,c,d,e, miR159,b, } \\
\text { miR160a,b,c,d,e, miR162, miR164b,c, } \\
\text { miR166a,b,c,d,e,f,g, miR167a,b,c,d,e,f,g, } \\
\text { miR168, miR169a,b,c,d,f,g,i, } \\
\text { miR171a,b,c,d,e,f, miR172a,b,c,e, } \\
\text { miR319, miR390, miR393, miR394, } \\
\text { miR395a,b,d,e,f, miR396a,b,c, miR397, } \\
\text { miR399a, b,c,d,e,f,g,h,i, miR408, } \\
\text { miR437, miR444, miR528, miR529, } \\
\text { miR821, miR1432, miR1435, miR1436, } \\
\text { miR1439 }\end{array}$ & $\begin{array}{l}\text { Rice miRNA } 169 \mathrm{~g}, \\
\text { upregulated during } \\
\text { drought stress } \\
\text { Cytochrome P450 } \\
\text { domain-containing genes, } \\
\text { often involved in } \\
\text { scavenging toxins such as } \\
\text { those accumulated in } \\
\text { response to stress }\end{array}$ & $\begin{array}{l}\text { Genome sequencing } \\
\text { Integration of shotgun } \\
\text { assembly with genetic and } \\
\text { physical maps } \\
\text {-Bioinformatics (BLAST) }\end{array}$ & [104] \\
\hline 7. & $\begin{array}{l}25 \text { miRNA families:miR395, miR169d, } \\
\text { miR172c, miR437g, miR169, miR172, } \\
\text { miR169a,b,c,d,e,f,g,h,i, miR172a, b,c,d,e, } \\
\text { miR395a,b,c,d,e,f,g,h, miR5381, } \\
\text { miR5382, miR5383, miR5384, miR5385, } \\
\text { miR5386, miR5387, miR5388, miR5389 }\end{array}$ & $\begin{array}{l}\text { Regulation biological } \\
\text { processes other than the } \\
\text { sulfur metabolism }\end{array}$ & $\begin{array}{l}\text { SOLiD next generation } \\
\text { sequencing system, } \\
\text { Bioinformatics tools }\end{array}$ & [105] \\
\hline 8. & $\begin{array}{l}\text { miR156, miR159 miR160, miR164, } \\
\text { miR165, 166, miR167, miR168, miR169, } \\
\text { miR170/171, miR172, miR319, miR390, } \\
\text { miR393, miR394, miR395, miR396, } \\
\text { miR397, miR398, miR408, miR437, } \\
\text { miR444, miR528, miR529, miR530, } \\
\text { miR827, miR894, miR1126, miR1318, } \\
\text { miR1436, miR2118, miR2910, } \\
\text { tasiRNA3a, tasiRNA3b, miR5564a, } \\
\text { miR5566, miR5568, miR5387b, } \\
\text { miR5569, miR5570, miR5565, c, d, e, f, } \\
\text { miR5564b, miR5567 }\end{array}$ & $\begin{array}{l}\text { Drought tolerance, } \\
\text { physiological processes } \\
\text { and biotic and abiotic } \\
\text { stress responses } \\
\text { The predicted targets are } \\
\text { pre- dominantly } \\
\text { transcription factors: } \\
\text { miR156 is predicted to } \\
\text { target } 7 \text { Squamosa } \\
\text { promoter binding } \\
\text { transcription factors; } \\
\text { miR159, } 4 \text { MYB } \\
\text { transcription factors; } \\
\text { miR160, } 6 \text { auxin } \\
\text { response factors }\end{array}$ & $\begin{array}{l}\text { Bioinformatics tools } \\
\text { (prediction of miRNA } \\
\text { targets, BLAST) (5'RACE) } \\
\text { assay }\end{array}$ & [59] \\
\hline 9. & $\begin{array}{l}\text { sbi-miR156j,k,l,m, miR166l, } \\
\text { miR166m,n,o,p,q,r,s,t, miR167j,k, } \\
\text { miR168b,c, miR1711,m, miR390b, } \\
\text { miR396f,g,h,i,j,k, miR398b, miR399l, } \\
\text { miR444a,b,c }\end{array}$ & $\begin{array}{l}\text { In leaf development, and } \\
\text { evolutionarily conserved } \\
\text { in all land plants. } \\
\text { Regulates expression } \\
\text { of the HD-ZIP III (class- } \\
\text { III homeodomain-leucin } \\
\text { zipper) miR444 family } \\
\text { members are conserved } \\
\text { only in monocot species }\end{array}$ & $\begin{array}{l}\text { Bioinformatics tools (used } \\
\text { ESTs and GSS to predict } \\
\text { miRNAs) }\end{array}$ & [106] \\
\hline
\end{tabular}




\begin{tabular}{|c|c|c|c|c|}
\hline 10. & $\begin{array}{l}\text { sbi-miR164,b,c, miR395a,f,k,i, } \\
\text { miR399a,b, }\end{array}$ & $\begin{array}{l}\text { Drought affected gene } \\
\text { expression. Regulation } \\
\text { of transcription (bZIPs, } \\
\text { MYBs, HOXs), signal } \\
\text { transduction } \\
\text { (phosphoesterases, } \\
\text { kinases, phosphatases), } \\
\text { carbon metabolism } \\
\text { (NADP-ME), } \\
\text { detoxification (CYPs, } \\
\text { GST, AKRs), } \\
\text { osmoprotection } \\
\text { mechanisms (P5CS) and } \\
\text { stability of protein } \\
\text { membranes (DHN1, } \\
\text { LEA, HSPs) }\end{array}$ & $\begin{array}{l}\text { Transcriptome analysis } \\
\text { using a high density } \\
\text { microarray } \\
\text { Bioinformatics tools } \\
\text { (analysis of drought-related } \\
\text { genes and stay green QTLs) }\end{array}$ & [108] \\
\hline 11. & $\begin{array}{l}\text { sbi-miR44, miR94, miR105a,b, miR108, } \\
\text { miR114, miR131, miR141, miR149, } \\
\text { miR182a,b, miR191, miR192, miR205, } \\
\text { miR221a-h, miR224, miR229, miR255, } \\
\text { miR263a-c, miR269, miR313, miR322, } \\
\text { miR324, miR337, miR383 } \\
\text { down-regulated under drought } \\
\text { miR169d-1, miR529, miR57, miR111, } \\
\text { miR211, miR245, miR266, miR339, } \\
\text { miR387 } \\
\text { up-regulated in M35but down regulated } \\
\text { in C43 } \\
\text { miR160a, miR396b-c, miR396d-e, } \\
\text { miR5385, miR4, miR6, miR19, miR26, } \\
\text { miR41, miR46, miR48, miR76a-d, } \\
\text { miR82, miR87, miR119, miR138, } \\
\text { miR144, miR151, miR164, miR259, } \\
\text { miR176, miR178a-b, miR180a-c, } \\
\text { miR212, miR240, miR285, miR287, } \\
\text { miR292, miR304, miR310a-e, miR314a- } \\
\text { c, miR316, miR335, miR336, miR340, } \\
\text { miR351, miR368, miR373, miR385, } \\
\text { miR390, miR391, miR392a-c, miR412, } \\
\text { miR413, miR416 } \\
\text { down-regulated in M35 but up regulated } \\
\text { in C43 } \\
\text { miR2118e, miR2275, miR36, miR59a-c, } \\
\text { miR64, miR120a-b, miR200, miR215, } \\
\text { miR223, miR227a-c, miR256, miR268, } \\
\text { miR295, miR297a-c, miR301, miR344, } \\
\text { miR359, miR360a-c, miR376 }\end{array}$ & $\begin{array}{l}\text { Drought stress } \\
\text { expression } \\
\text { miRNAs were found to } \\
\text { be involved in cellular, } \\
\text { metabolic, response to } \\
\text { stimulus, biological } \\
\text { regulation, and } \\
\text { developmental processes }\end{array}$ & $\begin{array}{l}\text { Next-generation } \\
\text { sequencing, } \\
\text { Small RNA Library } \\
\text { Construction and } \\
\text { Sequencing, Bioinformatics } \\
\text { Analysis of sRNA } \\
\text { Sequences, Differential } \\
\text { Expression Analysis of } \\
\text { miRNAs }\end{array}$ & [109] \\
\hline 12. & $\begin{array}{l}\text { miR156d, miR156, miR159a, } \\
\text { miR167c,g,f, miR168, miR393a,b, } \\
\text { miR160f, miR166a-d, miR166f, miR168, } \\
\text { miR171, miR399b, miR1435b }\end{array}$ & $\begin{array}{l}\text { Regulation of salinity } \\
\text { stress and drought stress }\end{array}$ & RT-qPCR & [110] \\
\hline 13. & $\begin{array}{l}\text { sbi-miR171h, miR5567, miR171d, } \\
\text { miR528, miR166j, miR167d, miR156d, }\end{array}$ & $\begin{array}{l}\text { Sequenced the sorghum } \\
\text { transcriptome o identify }\end{array}$ & $\begin{array}{l}\text { Bioinformatics tool } \\
\text { (BLAST), RT-PCR, RNA- }\end{array}$ & [111] \\
\hline
\end{tabular}




\begin{tabular}{|c|l|l|l|l|}
\hline & $\begin{array}{l}\text { miR5568d, miR1432, miR5568f, } \\
\text { miR319a, miR5567, miR159a, miR408, } \\
\text { miR168, miR397, miR166d, miR396c, } \\
\text { miR6225, miR169k, miR169l, } \\
\text { miR5565g, miR5567, miR399h, } \\
\text { miR156e, miR167c, miR166h }\end{array}$ & $\begin{array}{l}\text { full-length splice } \\
\text { isoforms and APA sites. }\end{array}$ & $\begin{array}{l}\text { sequencing, Differential } \\
\text { gene expression analysis }\end{array}$ \\
\hline 14. & $\begin{array}{l}\text { miR396, miR393, miR397-5p, miR166, } \\
\text { miR167, miR168 }\end{array}$ & $\begin{array}{l}\text { Regulate drought and } \\
\text { other abiotic stresses }\end{array}$ & expression profiling & {$[112]$} \\
\hline
\end{tabular}

\section{Conclusion}

Under hot and dry weather conditions, sweet sorghum is best choice as bioethanol to deal economic and environmental concerns. In transport sector biofuels are highly promoted. Recently, majority of research focuses on development of renewable resources, sustainable development, and environmentally friendly process. Use of sorghum biomass for energy purposes is of particular importance today because it allows reduction of greenhouse gases. Bioethanol is by far the most used biofuel for transport around the world. Although identification of potential miRNAs feedstocks have improvised and enhanced bioethanol production, one area of research possible in the future could explore the role of miRNAs in the factors of digestion, including the possible manipulation of miRNAs in microbial communities to improve biodegradability. In future miRNAs could be another way to enhance selective characteristics to biofuel production mechanisms.

\section{Acknowledgments}

This paper is a part of the research project (Pakistan-U.S. Science and Technology Cooperation Program, Phase-VI) financed by the higher education commission (HEC) of Pakistan, Islamabad. The authors highly thankful and acknowledged this financial support of the higher education commission (HEC) of Pakistan, Islamabad.

\section{Authors' contributions}

Data collected by: SH Ali \& M Din, Wrote Paper: SH Ali, MYK Barozai \&AN Azziz.

\section{References}

1. Monti A, Nissen L, Myrsini C \& Alexopoulou E (2012). Non-food Cropsto-Industry schemes in EU27" WP1. Non-food crops D1.3 Carbohydrate crops that can be produced in EU27. http://www.crops2industry.eu/images/pdf /pdf/D1\%203 UNIBO final.pdf

2. Ullah, Z, Buckley MS, Arnosti DN \& Henry RW (2007). Retinoblastoma protein regulation by the COP9 signalosome. Molecular biology of the cell, 18(4): 1179-1186.

3. Abdullah M \& Chaudhry MT (1996). Improved fodder and seed production in central irrigated Punjab. Proc. Of National Conference on the Improvement Production and utilization of fodder crops in Pakistan, March 25- 27 held at NARC, Islamabad, Pakistan. 55-62.

4. Habib N, Tahir A \& ul Ain Q (2013). Current situation and future outlook of sorghum area and production in Pakistan. Asian Journal of Agriculture and Rural Development 3(5): 283.

5. Tabbasam N \& Zafar Y (2006). DNAbased genotyping of sorghum hybrids. Pakistan Journal of Botany (Pakistan).

6. Mehmood S, Bashir A, Ahmad A, Akram Z, Jabeen N \& Gulfraz M (2008). Molecular characterization of regional Sorghum bicolor varieties from Pakistan. Pak. J. Bot 40(5): 2015-2021.

7. Iqbal A, Sadia B, Khan AI, Awan FS, Kainth RA \& Sadaqat HA (2010). Biodiversity in the sorghum (Sorghum bicolor L. Moench) germplasm of 
Pakistan. Genetics and Molecular Research 9(2): 756-764.

8. Bibi A, Sadaqat HA, Akram HM \& Mohammed MI (2010). Physiological markers for screening sorghum (Sorghum bicolor) germplasm under water stress condition. Int. J. Agric. Biol 12(3): 451455.

9. Mahmood T, Iqbal N, Raza H, Qasim M \& Ashraf MY (2010). Growth modulation and ion partitioning in salt stressed sorghum (Sorghum bicolor L.) by exogenous supply of salicylic acid. Pak. J. Bot 42(5): 3047-3054.

10. Nawaz K, Talat A, Hussain $K$ \& Majeed A (2010). Induction of salt tolerance in two cultivars of sorghum (Sorghum bicolor L.) by exogenous application of proline at seedling stage. World Applied Sciences Journal 10(1): 93-99.

11. Akram Z, Khan MM, Shabbir G \& Nasir F (2011). Assessment of genetic variability in sorghum genotypes for drought tolerance based on RAPD analysis. $J$. Agric. Res 49(4):

12. Ali MA, Abbas A, Awan SI, Jabran K \& Gardezi SDA (2011). Correlated response of various morphophysiological characters with grain yield in sorghum landraces at different growth phases. J Animal Plant Sci 21(4): 671679.

13. Hussain N, Baloch MS, Yousaf M, Naeem M, Khakwani AA \& Begum I (2011). Performance of sorghum varieties in potohar region.Gomal University Journal of Research 27, 2.

14. Sher A, Barbanti L, Ansar M, Manaf A \& Kaleem S (2011). Late harvest associated with $\mathrm{P}$ and $\mathrm{S}$ fertilization enhances yield and quality of forage sorghum (Sorghum bicolor L.) Moench), grown as a rainfed crop in Pakistan. Afr J Agric Res 6: 62326239.

15. Saleem A, Javed HI, Saleem R, Ansar M \& Zia MA (2011). Effect of split application of potash fertilizer on maize and sorghum in Pakistan. Pakistan J. Agric. Res 24(1-4).

16. Kausar A, Ashraf MY, Ali I, Niaz M \& Abbass QAISER (2012). Evaluation of sorghum varieties/lines for salt tolerance using physiological indices as screening tool. Pakistan Journal of Botany 44(1): 47-52.

17. Waqas HM, Firdous A, Ilyas M, Ashraf M, Zaka S, Zafar M \& Shaheen Z (2012). Effect of $\mathrm{NiCl}$ on the Morphology of Sorghum bicolor.

18. Shehzad M, Ayub M, Ahmad AUH \& Yaseen M (2012). Influence of priming techniques on emergence and seedling growth of forage sorghum (Sorghum bicolor L.). J Ani Plant Sci 22: 154-158.

19. Bibi A, Sadaqat HA, Tahir MHN \& Akram HM (2012). Screening of sorghum (Sorghum bicolor var Moench) for drought tolerance at seedling stage in polyethylene glycol.J. Anim. Plant Sci 22(3): 671-678.

20. Ayub M, Khalid M, Tariq M, Elahi M \& Nadeem MA (2012). Comparison of sorghum genotypes for forage production and quality. Journal of Animal and Plant Sciences 22: 733-737.

21. Zahid A, Khanum A, Ansar M \& Malik MA (2012). Effect of cutting and postcutting intervals on hydrogen cyanide in sorghum forage grown under rain-fed conditions.Pakistan Journal Of Botany 44(3): 955-960.

22. Mubeen K, Nadeem MA, Tanveer A \& Zahir ZA (2012). Allelopathic effects of sorghum and sunflower water extracts on germination and seedling growth of rice (Oryza sativa L.) and three weed species. The Journal of Animal and Plant Sciences 22(3): 738-746.

23. Khan AH, Chohan MSM \& Husnain SK (2013). Sorghum-2011: A new dual purpose Sorghum bicolor cultivar for 
agro-climatic conditions of Pakistan. $J$. Agric. Res 51(1).

24. Akhtar MF, Ahmad AUH, Zamir I, Shahid M, Khalid F, Mohsin AU \& Afzal M (2013). Agro-qualitative studies on forage sorghum (Sorghum bicolor 1.) Sown alone and in mixture with forage legumes. Pakistan Journal of Science 65(2).

25. Sher A, Barbanti L, Ansar M \& Malik MA (2013). Growth response and plant water status in forage sorghum [Sorghum bicolor (L.) Moench] cultivars subjected to decreasing levels of soil moisture. Australian Journal of Crop Science 7(6): 801.

26. Hayyat MU, Mahmood R, Hassan SW \& Rizwan S (2013). Effects of textile effluent on growth performance of Sorghum vulgare Pers CV. SSG5000. Biologia 59: 15-22.

27. Tariq AS, Akram Z, Shabbir G, Khan KS \& Iqbal MS (2014). Heterosis and combining ability studies for quantitative traits in fodder sorghum (Sorghum bicolor L). J. Agric. Res 52(3).

28. Rana AS, Ahmad AH, Saleem N, Nawaz A, Hussain $\mathrm{T}$ \& Saad M (2014). Differential response of sorghum cultivars for fodder Yield and quality. $J$. Glob. Innov. Agric. Soc. Sci 2(1): 6-10.

29. Raza I \& Naheed S (2014) Relationship among Biometrical Characters of Sorghum (Jowar) Hybrid. Sci. Tech. and Dev 33 (4): 175-177

30. Saddam S, Bibi A, Sadaqat HA \& Usman BF (2014). Comparison of 10 sorghum (Sorghum bicolor L) genotypes under various water stress regimes. JAPS, Journal of Animal and Plant Sciences 24(6): 1811-1820.

31. Kausar ABIDA, Ashraf MY \& Niaz M (2014). Some physiological and genetic determinants of salt tolerance in sorghum (Sorghum bicolor (L.) Moench): Biomass production and metabolisim. Pakistan Journal of Botany 46(2): 515-519.

32. Akram W, Anjum T, Ahmad A \& Moeen R (2014). First report of Curvularia lunata causing leaf spots on Sorghum bicolor from Pakistan. Plant Disease 98(7): 1007-1007.

33. Kandhro MN, Tunio S, Rajpar I \& Chachar QA (2014). Allelopathic impact of sorghum and sunflower intercropping on weed management and yield enhancement in cotton. Sarhad Journal of Agriculture 30(3): 311-8.

34. Mehmood S, Zamir S, Rasool T \& Akbar W (2014). Effect of Tillage and Mulching on Soil Fertility and Grain Yield of Sorghum. Sci. Agri 8 (1): 31-36

35. Sharif M, Arif M, Burni T, Khan F, Jan B \& Khan I (2014). Growth and phosphorus uptake of sorghum plants in salt affected soil as affected by organic materials Composted with rock phosphate. Pakistan Journal of Botany 46(1): 173-180.

36. Qadir M, Bibi A, Tahir MH, Saleem M \& Sadaqat HA (2015). Screening of sorghum (Sorghum bicolor L) genotypes under various levels of drought stress. Maydica 60: M35.

37. Ghani A, Saeed M, Hussain D, Shafique MM, Arshad M \& Shah SAS (2015). Evaluation of different sorghum (Sorghum bicolor L. moench) varieties for grain yield and related characteristics. Science Letters 3(2): 7274.

38. Yaqoob M, Hussain N \& Rashid A (2015). Genetic variability and heritability analysis for yield and morphological traits in sorghum (Sorghum bicolor L. Moench) genotypes. Journal of Agricultural Research 53(3).

39. Bakhsh A, Zahid MS, Shafeeq S, Gurmani ZA \& Khan S (2015). Comparison of green fodder yield in 
Sorghum varieties under rainfed conditions of Islamabad. Life Sciences International Journal 9: 3146-3149.

40. Bacaha N, Shamas R, Bakht J \& Rafi A (2015). Effect of heavy metal and EDTA application on plant growth and phytoextraction potential of sorghum (Sorghum bicolor). Pakistan Journal of Botany 47(5): 1679-1684.

41. Kandhro MN, Memon HR, Ansari MA \& Shah AN (2015). Effect of allelopathic water extract of sorghum and sunflower on weed mortality and cotton yield. Sarhad Journal of Agriculture 31(3): 165-174.

42. Kandhro MN, Laghari M, Baloch AW \& Ansari MA (2016). Allelopathic Impact of Sorghum and Sunflower on Germinability and Seedling Growth of Cotton (Gossypium hirsutum L.). Journal of Basic and Applied Sciences, 12: 98102.

43. Monk RL, Miller FR \& McBee GG (1984). Sorghum improvement for energy production. Biomass 6(1): 145-153.

44. Smith GA, Bagby MO, Lewellan RT, Doney DL, Moore PH, Hills FJ \& Freeman K (1987). Evaluation of sweet sorghum for fermentable sugar production potential. Crop Science 27(4): 788-793.

45. Smith GA \& Buxton DR (1993). Temperate zone sweet sorghumethanol production potential. Bioresource Technology 43(1): 71-75.

46. Woods J (2001). The potential for energy production using sweet sorghum in southern Africa. Energy for Sustainable Development 5(1): 31-38.

47. Monti A \& Venturi G (2003). Comparison of the energy performance of fibre sorghum, sweet sorghum and wheat monocultures in northern Italy.European Journal of Agronomy 19(1): 35-43.

48. Murray SC, Rooney WL, Mitchell SE, Sharma A, Klein PE, Mullet JE \&
Kresovich S (2008). Genetic improvement of sorghum as a biofuel feedstock: II. QTL for stem and leaf structural carbohydrates. Crop science 48(6): 2180-2193.

49. Murray SC, Sharma A, Rooney WL, Klein PE, Mullet JE, Mitchell SE \& Kresovich $S$ (2008). Genetic improvement of sorghum as a biofuel feedstock: I. QTL for stem sugar and grain nonstructural carbohydrates. Crop Science 48(6): 21652179.

50. Zhao YL, Dolat A, Steinberger Y, Wang X, Osman A \& Xie GH (2009). Biomass yield and changes in chemical composition of sweet sorghum cultivars grown for biofuel. Field Crops Research 111(1): 55-64.

51. Miller AN \& Ottman MJ (2010). Irrigation frequency effects on growth and ethanol yield in sweet sorghum. Agronomy Journal 102(1): 60-70.

52. Wortmann CS, Liska AJ, Ferguson RB, Lyon DJ, Klein RN \& Dweikat I (2010). Dryland performance of sweet sorghum and grain crops for biofuel in Nebraska. Agronomy Journal 102(1): 319-326.

53. Economou CN, Makri A, Aggelis G, Pavlou S \& Vayenas DV (2010). Semisolid state fermentation of sweet sorghum for the biotechnological production of single cell oil. Bioresource technology 101(4): 1385-1388.

54. Audilakshmi S, Mall AK, Swarnalatha M \& Seetharama N (2010). Inheritance of sugar concentration in stalk (brix), sucrose content, stalk and juice yield in sorghum. Biomass and Bioenergy 34(6): 813-820.

55. 54.Mosalia J, Rogersa J, Huhnkeb R, Bellmerb D \& Cooka B (2010). Effect of nitrogen fertilization timing on juice and bagasse quality of sweet sorghum for biofuel production. In 19 th World 
Congress of Soil Science, Soil Solutions for a Changing World (pp. 1-6).

56. Guigou M, Lareo C, Pérez LV, Lluberas ME, Vázquez D \& Ferrari MD (2011). Bioethanol production from sweet sorghum: Evaluation of post-harvest treatments on sugar extraction and fermentation. biomass and bioenergy 35(7): 3058-3062.

57. Vasilakoglou I, Dhima K, Karagiannidis N \& Gatsis $\mathrm{T}$ (2011). Sweet sorghum productivity for biofuels under increased soil salinity and reduced irrigation. Field Crops Research 120(1): 38-46.

58. Xu F, Shi YC, Wu X, Theerarattananoon K, Staggenborg S \& Wang D (2011). Sulfuric acid pretreatment and enzymatic hydrolysis of photoperiod sensitive sorghum for ethanol production. Bioprocess and biosystems engineering 34(4): 485-492.

59. Zhang $\mathrm{T}, \mathrm{Du} \mathrm{N} \&$ Tan $\mathrm{T}$ (2011). Biobutanol production from sweet sorghum bagasse. Journal of Biobased Materials and Bioenergy 5(3): 331-336

60. Ananda N, Vadlani PV \& Prasad PV (2011). Evaluation of drought and heat stressed grain sorghum (Sorghum bicolor) for ethanol production.Industrial Crops and Products 33(3): 779-782.

61. Kim M, Han KJ, Jeong Y \& Day DF (2012). Utilization of whole sweet sorghum containing juice, leaves, and bagasse for bio-ethanol production. Food Science and Biotechnology 21(4): 10751080.

62. Qureshi Z, Mehmood S, Hassan MU, Hyder MZ, Malik MF, Gulfraz M \& Akhtar N (2012). Simultaneous Saccharification and Fermentation of Sorghum Bicolour Grains by Ethanol and Sugar Tolerated Saccharomyces cerevisiae. Asian Journal of Chemistry 24(3): 1162.

63. Erickson JE, Woodard KR \& Sollenberger LE (2012). Optimizing sweet sorghum production for biofuel in the southeastern USA through nitrogen fertilization and top removal. Bioenergy Research 5(1): 86-94.

64. Holou RA \& Stevens G (2012). Juice, sugar, and bagasse response of sweet sorghum (Sorghum bicolor (L.) Moench cv. M81E) to $\mathrm{N}$ fertilization and soil type. GCB Bioenergy 4(3): 302-310.

65. Sambusiti C, Ficara E, Malpei F, Steyer JP \& Carrère H (2013). Effect of sodium hydroxide pretreatment on physical, chemical characteristics and methane production of five varieties of sorghum. Energy 55: 449-456.

66. Rutto LK, Xu Y, Brandt M, Ren S \& Kering MK (2013). Juice, ethanol, and grain yield potential of five sweet sorghum (Sorghum bicolor [L.] Moench) cultivars.

67. Martin AP, Palmer WM, Byrt CS, Furbank RT \& Grof CP (2013). A holistic highthroughput screening framework for biofuel feedstock assessment that characterises variations in soluble sugars and cell wall composition in Sorghum bicolor. Biotechnology

68. Kamireddy SR, Li J, Abbina S, Berti M, Tucker M \& Ji Y (2013). Converting forage sorghum and sunn hemp into biofuels through dilute acid pretreatment. Industrial Crops and Products 49: 598-609.

69. Choudhary SJ, Mehmood S \& Naz H (2013). Optimization of pretreatment conditions of sorghum bicolor straw, a substrate for bioethanol production: A pilot study. Pakistan Journal of Biochemistry and Molecular Biology 46(2): 80-84.

70. Rao SS, Patil JV, Umakanth AV, Mishra JS, Ratnavathi CV, Prasad GS \& Rao BD (2013). Comparative performance of sweet sorghum hybrids and open pollinated varieties for millable stalk yield, biomass, sugar quality traits, grain 
yield and bioethanol production in tropical Indian condition. Sugar Tech 15(3): 250-257.

71. Dutra ED, Neto AGB, de Souza RB, de Morais Junior MA, Tabosa JN \& Menezes RSC (2013). Ethanol Production from the Stem Juice of Different Sweet Sorghum Cultivars in the State of Pernambuco, Northeast of Brazil. Sugar Tech 15(3): 316-321.

72. Theuretzbacher F, Bauer A, Lizasoain J, Becker M, Rosenau T, Potthast A \& Gronauer A (2013). Potential of different Sorghum bicolor (L. moench) varieties for combined ethanol and biogas production in the Pannonian climate of Austria. Energy 55: 107-113.

73. Vandenbrink JP, Hammonds RE, Hilten RN, Das KC, Henson JM, Paterson AH $\&$ Feltus FA (2013). Tissue specific analysis of bioconversion traits in the bioenergy grass Sorghum bicolor. Industrial Crops and Products 50: 118-130.

74. Cotton J, Burow G, Acosta-Martinez V \& Moore-Kucera J (2013). Biomass and cellulosic ethanol production of forage sorghum under limited water conditions. BioEnergy Research 6(2): 711-718.

75. Dalla Marta A, Mancini M, Orlando F, Natali F, Capecchi L \& Orlandini S (2014). Sweet sorghum for bioethanol production: Crop responses to different water stress levels. Biomass and Bioenergy 64: 211-219.

76. Cifuentes R, Bressani R \& Rolz C (2014). The potential of sweet sorghum as a source of ethanol and protein. Energy for Sustainable Development 21: 13-19.

77. Fernandes G, Braga TG, Fischer J, Parrella RA, de Resende MM \& Cardoso VL (2014). Evaluation of potential ethanol production and nutrients for four varieties of sweet sorghum during maturation. Renewable Energy 71: 518524.

78. Cuevas HE, Prom LK \& Erpelding JE (2015). Tapping the US sweet sorghum collection to identify biofuel germplasm. Sugar Tech 17(4): 428-438.

79. Mocoeur A, Zhang YM, Liu ZQ, Shen X, Zhang LM, Rasmussen SK \& Jing HC (2015). Stability and genetic control of morphological, biomass and biofuel traits under temperate maritime and continental conditions in sweet sorghum (Sorghum bicolour). Theoretical and Applied Genetics 128(9): 1685-1701.

80. Mukabane BG, Thiongo G, Gathitu BB, Murage H \& Owino WO (2015). Bioethanol Production from Enzymatic Hydrolysis of Rio Sweet Sorghum Bagasse Grown in Kenya. The International Journal of Science and Technoledge 3(4): 174.

81. Khalil SR, Abdelhafez AA \& Amer EAM (2015). Evaluation of bioethanol production from juice and bagasse of some sweet sorghum varieties. Annals of Agricultural Sciences.

82. Xuan TD, Phuong NT, Khang DT \& Khanh TD (2015). Influence of Sowing Times, Densities, and Soils to Biomass and Ethanol Yield of Sweet Sorghum. Sustainability 7(9): $\quad$ 1165711678.

83. Maw MJ, Houx JH \& Fritschi FB (2016). Sweet sorghum ethanol yield component response to nitrogen fertilization. Industrial Crops and Products 84: 43-49.

84. Mengistu MG, Steyn JM, Kunz RP, Doidge I, Hlophe HB, Everson CS \& Clulow AD (2016). A preliminary investigation of the water use efficiency of sweet sorghum for biofuel in South Africa. Water SA 42(1): 152-160.

85. Barozai MYK, Baloch IA \& Din M (2012) Identification of MicroRNAs and their 
targets in Helianthus. Mol. Biol. Rep. 39 (3), 2523-2532.

86. Baloch IA, Barozai MYK, Din M (2013). MicroRNAs: the mega regulators in eukaryotic genomes. Pure Appl. Biol. 2 (3), 83-88.

87. Matts J, Jagadeeswaran G, Roe BA \& Sunkar R (2010). Identification of microRNAs and their targets in switchgrass, a model biofuel plant species. Journal of plant physiology 167(11): 896-904.

88. Xie F, Frazier TP \& Zhang B (2010). Identification and characterization of microRNAs and their targets in the plant switchgrass (Panicum virgatum). Planta 232(2): 417-434.

89. Zanca AS, Vicentini R, Ortiz-Morea FA, Del Bem LE, da Silva MJ, Vincentz M \& Nogueira FT (2010). Identification and expression analysis of microRNAs and targets in the biofuel crop sugarcane. BMC plant biology 10(1): 1.

90. Zhang G, Liu X, Quan Z, Cheng S, Xu X, Pan S\& Tao Y (2012). Genome sequence of foxtail millet (Setaria italica) provides insights into grass evolution and biofuel potential. Nature biotechnology 30(6): 549-554.

91. Fu C, Sunkar R, Zhou C, Shen H, Zhang JY, Matts J \& Wang ZY (2012). Overexpression of miR156 in switchgrass (Panicum virgatum L.) results in various morphological alterations and leads to improved biomass production. Plant biotechnology journal 10(4): 443-452.

92. Sun G, Stewart Jr CN, Xiao P \& Zhang B (2012). MicroRNA expression analysis in the cellulosic biofuel crop switchgrass (Panicum virgatum) under abiotic stress. PLoS One 7(3): e32017.

93. Ferreira TH, Gentile A, Vilela RD, Costa GGL, Dias LI, Endres L \& Menossi M (2012). microRNAs associated with drought response in the bioenergy crop sugarcane (Saccharum spp.). PLoS One 7(10): e46703.

94. Jeong DH, Schmidt SA, Rymarquis LA, Park S, Ganssmann M, German MA, Accerbi M, Zhai, J, Fahlgren N, Fox SE, Garvin DF, Mockler TC, Carrington JC, Meyers BC \& Green PJ (2013a). Parallel analysis of RNA ends enhances global investigation of microRNAs and target RNAs of Brachypodium distachyon.Genome Biol 14: R145.

95. Green PJ, Jeong DH, Schmidt SA, Rymarquis LA, Park S, Ganssmann M, German MA, Accerbi M, Zhai, J, Fahlgren N, Fox SE, Garvin DF, Mockler TC, Carrington JC \& Meyers BC (2013a). Parallel analysis of RNA ends enhances global investigation of microRNAs and target RNAs of Brachypodium distachyon.Genome Biol 14: R145.

96. Green PJ (2015). Genome-Wide Analysis of miRNA targets in Brachypodium and Biomass Energy Crops (No. DOE-UDER64450). University of Delaware.

97. Muthamilarasan M, Khan Y, Jaishankar J, Shweta S, Lata C \& Prasad M (2015). Integrative analysis and expression profiling of secondary cell wall genes in C4 biofuel model Setaria italica reveals targets for lignocellulose bioengineering. Frontiers in plant science 6: 965.

98. Trumbo JL, Zhang B \& Stewart CN (2015). Manipulating microRNAs for improved biomass and biofuels from plant feedstocks. Plant biotechnology journal 13(3): 337-354.

99. Bedell JA, Budiman MA, Nunberg A, Citek RW, Robbins D, Jones J \& McMenamy J (2005). Sorghum genome sequencing by methylation filtration. PLoS Biol 3(1): e13.

100. Dezulian T, Palatnik JF, Huson D \& Weigel D (2005). Conservation and 
divergence of microRNA families in plants. Genome Biology 6(11): 1.

101.Zhang BH, Pan XP, Wang QL, George P

$C$ \& Anderson TA (2005). Identification and characterization of new plant microRNAs using EST analysis. Cell research 15(5): 336-360.

102. Zhang B, Pan X, Cannon CH, Cobb GP \& Anderson TA (2006). Conservation and divergence of plant microRNA genes. The Plant Journal 46(2): 243-259.

103.Zhang L, Chia JM, Kumari S, Stein JC, Liu Z, Narechania A \& Ware D (2009). A genome-wide characterization of microRNA genes in maize. PLoS Genet 5(11): e1000716.

104. Paterson AH, Bowers JE, Bruggmann R, Dubchak I, Grimwood J, Gundlach H \& Schmutz J (2009). The Sorghum bicolor genome and the diversification of grasses. Nature 457(7229): 551-556.

105. Calvino M, Bruggmann R \& Messing J (2011). Characterization of the small RNA component of the transcriptome from grain and sweet sorghum stems. BMC genomics, 12(1): 1.

106. Katiyar A， Smita S, Chinnusamy V, Pandey DM \& Bansal K (2012). Identification of miRNAs in sorghum by using bioinformatics approach. Plant signaling \& behavior, 7(2): 246-259.

107. Thiebaut F, Grativol C, Carnavale-Bottino M, Rojas CA, Tanurdzic M, Farinelli L \& Ferreira PCG (2012). Computational identification and analysis of novel sugarcane microRNAs. BMC genomics, 13(1): 1 .

108. Pasini L, Bergonti M, Fracasso A, Marocco A \& Amaducci S (2014). Microarray analysis of differentially expressed mRNAs and miRNAs in young leaves of sorghum under dry-down conditions. Journal of plant physiology, 171(7): 537-548.

109. Katiyar A, Smita S, Muthusamy SK, Chinnusamy V, Pandey DM \& Bansal KC (2015). Identification of novel drought-responsive microRNAs and trans-acting siRNAs from Sorghum bicolor (L.) Moench by high-throughput sequencing analysis. Frontiers in plant science, 6.

110. El Sanousi RS, Hamza NB, Abdelmula AA, Mohammed IA, Gasim SM \& Sanan-Mishra N (2016). Differential Expression of miRNAs in Sorghum bicolor under Drought and Salt Stress.American Journal of Plant Sciences 7(06): 870.

111. Abdel-Ghany SE, Hamilton M, Jacobi JL, Ngam P, Devitt N, Schilkey F \& Reddy AS (2016). A survey of the sorghum transcriptome using single-molecule long reads. Nature Communications 7.

112. Hamza NB, Sharma N, Tripathi A \& Sanan-Mishra N (2016). MicroRNA expression profiles in response to drought stress in Sorghum bicolor. Gene Expression Patterns 20(2):88-98. 